\title{
PAY FOR BANKER PERFORMANCE: STRUCTURING EXECUTIVE COMPENSATION FOR RISK REGULATION
}

Frederick Tung*

INTRODUCTION 1206

I. The Bank Confidence Game ....

A. Bank Runs 1210

B. Deposit Insurance and Banker Moral Hazard ........ 1211

C. Bank Risk Regulation.

II. PAy For Performance AND the FinANCIAL CRisis. 1216

A. Pay for Performance for Shareholders 1216

B. The Evolution of Incentive Pay for Bankers 1218

C. Banker Pay Preceding the Crisis..... 1222

D. Post-Crisis Pay Constraints....

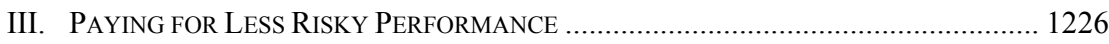

A. Inside Debt Compensation ...................................................................... 1227

B. Market Discipline through Public Subordinated Debt ............................. 1229

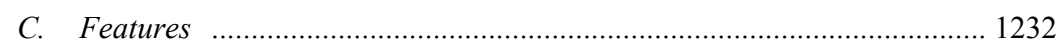

D. Bank-Level Debt to Counter Corporate Structure Effects......................... 1234

IV. COMPARING OTHER APPROACHES ..................................................................... 1241

A. Bhagat and Romano: Long-Term Restricted Stock .................................. 1241

B. Bebchuk and Spamann: Paying by the Slice ............................................. 1244

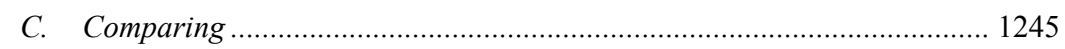

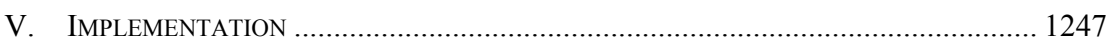

A. Setting Debt-Equity Targets ............................................................. 1248

B. Implementation Incentives ................................................................. 1249

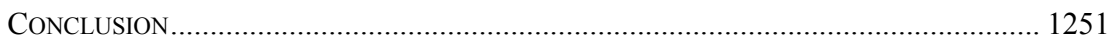

\footnotetext{
* Howard Zhang Faculty Research Scholar and Professor of Law, Boston University School of Law, fredtung@bu.edu. For helpful comments, I am grateful to Sanjai Bhagat, Jesse Fried, Michael Kang, John Mittelbach, Alon Raviv, Holger Spamann, and Chuck Whitehead, as well as workshop participants at the Canadian Law and Economics 2009 Annual Meeting, the Southeastern Association of Law Schools 2009 Annual Meeting, and the Boston University School of Law.
} 


\section{INTRODUCTION}

Excessive risk taking by firm managers did not originate with the financial crisis of 2007-2008. Though bankers had special incentives to take big risks in the period before the crisis, the incentive effects of equity-based compensation have been understood for some time. As Michael Jensen and William Meckling explained over three decades ago, in the presence of outside creditors, equity incentives may cause managers to go overboard, to take inefficient risks at the expense of creditors and others. ${ }^{1}$ For bankers, those incentives were writ large with the financial crisis, intensified as they were by the moral hazard that accompanies government guaranties of bank deposits. I propose to ameliorate this gamblers' incentive with a new approach to compensation at the largest banks, one that explicitly accounts for the possibility of excessive risk taking and incentivizes bankers against it. I propose that bankers be paid in part with their banks' public subordinated debt (sub debt) securities.

Constraining bank risk taking is an unending task for bank regulators, even outside the crisis context, because of certain special features of banks. Banks are highly leveraged - that is, they operate predominantly on borrowed money. Bank executives also typically enjoy high levels of equitybased incentive pay. These two factors would encourage risky strategies in any firm because managers' equity stakes enjoy an unlimited upside return if a risky investment succeeds, but any losses are borne primarily by creditors when a risky investment fails. Creditors of ordinary (nonbanking) firms understand these incentives, so they typically negotiate contractual constraints on their borrower firms' risk taking. But banks are different: a significant group of creditors - namely, insured depositors - do not monitor banks' risk taking. Because deposits are insured by the government, bank depositors are indifferent as to their banks' risk taking. ${ }^{2}$ Regulators are therefore left with the task of constraining risk taking at banks. And regulation is imperfect.

Policy analysts have decried the role of executive compensation in promoting excessive risk taking leading up to the financial crisis, ${ }^{3}$ and Congress and regulators have imposed new constraints on banker pay. ${ }^{4}$ Aca-

\footnotetext{
${ }^{1}$ Michael C. Jensen \& William H. Meckling, Theory of the Firm: Managerial Behavior, Agency Costs and Ownership Structure, 3 J. FIN. ECON. 305, 333-34 (1976) (discussing the agency costs of debt versus equity); see infra note 53 and accompanying text.

${ }^{2}$ As the discussion implies, my focus is on commercial banks - deposit-taking institutions - and not investment banks or other types of "nonbank" financial institutions.

${ }^{3}$ Press Release, Bd. of Governors of the Fed. Reserve Sys. (Oct. 22, 2009), available at http://www.federalreserve.gov/newsevents/press/bcreg/20091022a.htm (quoting Federal Reserve Chairman Ben S. Bernanke) ("Compensation practices at some banking organizations have led to misaligned incentives and excessive risk-taking, contributing to bank losses and financial instability.... The Federal Reserve is working to ensure that compensation packages appropriately tie rewards to longerterm performance and do not create undue risk for the firm or the financial system.").

${ }^{4}$ See infra Part II.D.
} 
demics have likewise proposed banker pay reforms. ${ }^{5}$ Two important proposals have recently emerged - one by Lucian Bebchuk and Holger Spamann $^{6}$ and another by Sanjai Bhagat and Roberta Romano. ${ }^{7}$

Bebchuk and Spamann propose to pay bankers with a representative slice of all of their firm's securities - preferred stock and bonds as well as common equity. ${ }^{8}$ This approach would hopefully reduce risk taking, since preferred stockholders and bondholders generally prefer less risk than common shareholders do. ${ }^{9}$ Bhagat and Romano propose long-term equity pay for bankers. ${ }^{10}$ Bankers would be paid with stock they could not sell until several years after they retire from their firms on the theory that this lengthy holding period would induce bankers to adopt a long-term perspective in their decisionmaking. ${ }^{11}$

In this Article, I introduce a new approach to banker pay that offers important advantages over the Bebchuk-Spamann and Bhagat-Romano proposals. I propose that, in addition to equity, bank executives should receive some portion of their compensation in the form of their bank's publicly traded subordinated debt securities. ${ }^{12}$

Recent theoretical and empirical research shows that, as a CEO's holdings of her firm's debt increase relative to the value of her equity holdings - that is, as her "inside debt-equity ratio" increases - the firm's risk taking declines. ${ }^{13}$ Such inside debt holdings help to align managers' interests with those of their firms' creditors, who are more risk averse than equity holders. In a recent paper, Xue Wang and I empirically test for this

\footnotetext{
${ }^{5}$ See infra Part IV.A-B. A few scholars express some doubt as to the significance of bankers' compensation structures as a factor in precipitating the recent financial crisis. See, e.g., Compensation Structure and Systemic Risk: Hearing Before the H. Comm. on Fin. Servs., 111th Cong. 173-75 (2009) (statement of Kevin J. Murphy, Kenneth L. Trefftzs Chair in Finance, Marshall School of Business, University of Southern California); Rüdiger Fahlenbrach \& René M. Stulz, Bank CEO Incentives and the Credit Crisis, 99 J. Fin. ECON. 11 (2011).

${ }^{6}$ Lucian A. Bebchuk \& Holger Spamann, Regulating Bankers' Pay, 98 GEO. L.J. 247 (2010); see infra Part IV.B.

${ }^{7}$ Sanjai Bhagat \& Roberta Romano, Reforming Executive Compensation: Focusing and Committing to the Long-Term, 26 YALE J. ON REG. 359 (2009); see infra Part IV.A.

${ }^{8}$ See infra Part IV.B.

${ }^{9}$ Because preferred stockholders and bondholders do not enjoy the unlimited upside return that common shareholders do, preferred stockholders and bondholders eschew high-risk, potentially highreturn bets that, if successful, would generate large returns for common shareholders. Instead, preferred stockholders and bondholders prefer relatively lower risk, lower return strategies. See Clifford W. Smith, Jr. \& Jerold B. Warner, On Financial Contracting: An Analysis of Bond Covenants, 7 J. Fin. ECON. 117, 118-19 (1979) (explaining conflicts between bondholders and common shareholders over investment strategies).

${ }^{10}$ See infra Part IV.A

${ }^{11}$ See infra Part IV.A.

12 See infra Part III.B.

13 See infra Part III.A. The inside debt in these studies, including ours, is in the form of pension and deferred compensation obligations of the firm to the CEO.
} 
effect of inside debt in the specific context of the recent financial crisis. ${ }^{14}$ We offer important evidence that higher pre-crisis inside debt-equity ratios for bankers correlate with lower firm risk and better firm performance during the crisis. ${ }^{15}$ Paying bankers with debt may therefore curb their appetite for risk, consistent with regulators' goal of assuring bank safety and soundness.

Publicly traded subordinated bank debt may be an ideal form of debt compensation for bankers because market pricing of this debt will offer a continuing referendum on risk taking at the bank. If the bank fails, its subordinated debt will be repaid only after all depositors and general creditors were paid in full. Moreover, since subordinated debt claims are fixed, subordinated debtholders do not enjoy the unlimited upside from the bank's risky bets that equity holders do. Market pricing of the debt will therefore be particularly sensitive to downside risk, much more so than equity. These risk-related price fluctuations will directly affect bankers' wealth, giving bankers useful feedback and important incentives with respect to excessive risk taking.

My proposal provides two important advantages over existing proposals. First, it offers a more direct and reliable inducement for bankers to curb excessive risk taking. The largest banks are owned and operated as wholly owned subsidiaries of bank holding companies (BHCs), which also typically own other financial institutions. The Bebchuk-Spamann and BhagatRomano proposals would compensate bankers with holding company securities: long-term equity for Bhagat and Romano, and BHC common and preferred stock and bonds for Bebchuk and Spamann. But because BHCs own other financial institutions besides the given banking subsidiary, market pricing of BHC securities can offer bankers only noisy and indirect incentives with respect to risk taking at the bank. Market discipline works best if the bank itself issues the securities as opposed to the BHC of which it is a subsidiary. My approach is the first to explicitly overcome this problem by paying bankers with debt securities issued by the bank itself. ${ }^{16}$

\footnotetext{
${ }^{14}$ Frederick Tung \& Xue Wang, Bank CEOs, Inside Debt Compensation, and the Global Financial Crisis (Sept. 22, 2011) (unpublished manuscript), available at $\mathrm{http}: / / \mathrm{ssrn} . c 0 m / \mathrm{abstract}=1570161$.

${ }^{15}$ Id. at 3.

${ }^{16}$ Given the BHC structure and the variation of management structures within BHCs, the identification of the specific bank executives to be targeted for pay regulation may not be a straightforward task. The CEO and other top officers of a banking subsidiary should clearly be covered by my proposed pay constraints. Holding company officers may need to be covered as well. Holding company officers will typically have significant influence over policy decisions at banking subsidiaries and may even be officers of the banking subsidiaries. For example, Kenneth D. Lewis, the CEO, Chairman, and President of Bank of America Corporation, serves in these same capacities for Bank of America, N.A., its principal banking subsidiary. Bank of Am. Corp., Proxy Statement 16 (Mar. 18, 2009), available at http://media.corporate-ir.net/media_files/irol/71/71595/reports/2009_Proxy.pdf. When BHC officers wield important influence over a banking subsidiary's policy decisions, they should be made to hold subordinated debt of that bank. See infra Part III.D.
} 
In addition, my approach facilitates the tailoring of annual pay to achieve desirable portfolio incentives for bankers in a way that existing proposals cannot. The primary focus for structuring banker pay should be on managing bankers' personal portfolios of their firms' securities and other claims on their firms. ${ }^{17}$ These portfolios typically dwarf bankers' annual pay and so exert a much stronger influence on bankers' risk taking than does annual pay. Compensation should be structured primarily with these portfolio incentives in mind. ${ }^{18}$ The Bebchuk-Spamann "by-the-slice" approach does not directly respond to the problem of excessive risk. ${ }^{19} \mathrm{Be}-$ cause bankers' existing portfolios matter, and because the composition of their portfolios varies, countering a banker's tendency toward excessive risk requires something more tailored than simple by-the-BHC-slice compensation. Similarly, Bhagat and Romano's long-term BHC equity approach does nothing to address existing portfolio effects. ${ }^{20}$

Requiring bankers to hold their own banks' debt would not substitute for traditional external regulation but would offer an important supplement to the existing regulatory toolkit for constraining bank risk taking. Unlike existing tools, this one works by directly altering bank managers' personal incentives with regard to risk, ${ }^{21}$ and unlike existing reform proposals, it is sufficiently flexible to be able to tailor bankers' sensitivity to downside risk in light of their existing portfolios and their banks' specific circumstances. In Part I, I explain the special regulatory and governance problems of banks. High leverage combined with regulation-induced moral hazard make excessive risk taking a special problem at banks. Part II recounts the pay-for-performance movement and its effect on the evolution of incentive pay for bankers. The pay-for-performance movement coincided with a decades-long trend of banking deregulation. Together these overlapping trends have shaped the current equity-fueled structure of banker pay. Part III de-

\footnotetext{
17 The most important of these other claims are pension and deferred compensation claims, which exert a debt-like influence on managers. See infra Part III.A.

18 As with all executive pay proposals, hedging against the risks imposed by the pay structure would be strictly forbidden. Otherwise, the intended incentive structure would be frustrated.

19 See infra Part IV.B.

${ }^{20}$ Moreover, the Bhagat-Romano long-term BHC equity approach cannot offer the strong incentives that bank sub debt provides. In addition to the noisy proxy problem described above, long-term equity would offer only a weak incentive for bankers because of the long delay in realizing their rewards for good performance. This is exacerbated by the "control gap" they are forced to endure: during the period after retirement but before they can cash out their shares, they will have no influence over the firm's performance. Someone else will be in control. See infra Part IV.A.

${ }^{21}$ Kose John, Anthony Saunders \& Lemma W. Senbet, A Theory of Bank Regulation and Management Compensation, 13 REV. Fin. STUD. 95, 97 (2000) ("Unlike capital and asset regulations, which have at best indirect effects on managerial incentives and thus on managerial decisions, altering topmanagement compensation is a direct and effective way of influencing managerial return and risk-taking incentives.”). John, Saunders, and Senbet argue that FDIC deposit insurance pricing should account for bank managers' compensation arrangements. See id.
} 
scribes my banker pay proposal. Part IV describes and critiques existing proposals for reform. Part V discusses implementation issues.

\section{THE BANK CONFIDENCE GAME}

Banks depend on public confidence for their survival. Because of the importance of the financial system, the states and the federal government act to instill public confidence in banks. Since the 1930s, deposit insurance has been a critical element in this confidence game, ${ }^{22}$ but as with insurance generally, deposit insurance creates moral hazard: bankers take greater risks than they would without the insurance. This side effect requires government supervision of banking activities. This Part explains the basics of the bank confidence game, its potential for encouraging excessive risk taking at banks, and the difficulties of crafting an adequate regulatory response.

\section{A. Bank Runs}

Banks are special institutions and are very different from other businesses. First, they are highly leveraged. They carry far more debt, relative to the value of their assets, than most other businesses. With leverage, shareholders and their agents prefer riskier bets than if the firm had no debt because the payoffs from leveraged bets are asymmetric. Shareholders enjoy unlimited payoffs from a successful high-risk bet with borrowed money, but limited liability assures that they lose only the amount of their investment in the firm should the high-risk bet turn out badly. The remaining losses are born by the firm's creditors. ${ }^{23}$

In addition to high leverage, bank assets and liabilities are mismatched. ${ }^{24}$ Most of their liabilities are volatile, taking the form of customer deposits that must be repaid upon demand. Though it is relatively unlikely that all or even most of a bank's customers would demand repayment of their deposits concurrently, ${ }^{25}$ the demand nature of the liabilities means that banks are to some extent always dealing with uncertainty regarding their cash outlays. In essence, they worry that all (or a significant portion of) their loans - in the form of customers' deposits - will be called at once. ${ }^{26}$

\footnotetext{
${ }^{22}$ Deposit insurance protects depositors of insured banks from the risk of loss of their deposits if an insured bank fails. FED. DEPOSIT INS. CORP., YOUR INSURED DEPOSITS, http://www.fdic.gov/deposit/ deposits/insured/basics.html (last visited Oct. 1, 2011).

${ }^{23}$ See infra note 32.

${ }^{24}$ See Charles K. Whitehead, The Evolution of Debt: Covenants, the Credit Market, and Corporate Governance, 34 J. CORP. L. 641, 654-55 (2009) (describing the traditional banking function of balancing mismatched assets and liabilities).

${ }^{25}$ When this happens, of course, this is the dreaded bank run.

${ }^{26}$ Banking regulators set reserve requirements, mandating that banks hold some minimum amount of readily accessible funds to be able to meet depositors' withdrawal demands. Depository Institutions Deregulation and Monetary Control Act of 1980, 12 U.S.C. § 461 (2006) [hereinafter DIDMCA].
} 
Banks' assets, on the other hand, primarily take the form of longerterm loans-medium- to long-term promises of regular periodic payments from their borrowers. Because of this mismatch of relatively illiquid assets with extremely liquid liabilities, banks are vulnerable to runs. Historically, even rumors of a bank's imminent failure might set off a race among its depositors to withdraw their funds from the bank all at once. Of course, no bank holds cash sufficient to meet all of its depositors' simultaneous withdrawal demands. Banks lend almost all of their deposit money out. With a bank run, individual depositors face a collective action problem. If an individual depositor fears that many other depositors are racing to the bank to withdraw their funds, then that individual depositor is forced to do the same. She will want to get her money out while the bank still has cash. The run becomes a self-fulfilling prophecy, and the liquidity crunch will cause even a solvent bank to fail.

In this sense, then, commercial banking is something of a confidence game. While high leverage encourages risk taking, a commercial bank survives only as long as its depositors are confident of its continuing solvency and ability to meet withdrawal demands. Historically, banking laws have attempted various strategies to curb banks' risk taking and to improve depositor confidence in banks and the banking system as a whole. ${ }^{27}$ Today, federal deposit insurance serves as a principal bulwark for depositor confidence.

\section{B. Deposit Insurance and Banker Moral Hazard}

In the wake of the Great Depression, Congress established the Federal Deposit Insurance Corporation (FDIC) to insure the deposits of member banks. ${ }^{28}$ The federal guarantee of bank deposits prevents most runs because depositors are confident that FDIC insurance will cover failed banks' deposit liabilities. ${ }^{29}$

\footnotetext{
${ }^{27}$ For example, unlimited or double liability for bank shareholders was a common approach in the 1800s. See Jonathan R. Macey \& Maureen O'Hara, Solving the Corporate Governance Problems of Banks: A Proposal, 120 BANKING L.J. 326, 331 (2003). Double liability made bank shareholders personally liable for an amount equal to the amount they had invested in their shares of the bank. Id. Courts have also periodically imposed special fiduciary duties on bank directors during or after banking crises. See Patricia A. McCoy, A Political Economy of the Business Judgment Rule in Banking: Implications for Corporate Law, 47 CASE W. RES. L. REV. 1, 5 (1996) (describing the cyclicality of court decisions applying the business judgment rule to directors of failed banks); see also Macey \& O'Hara, supra, at 335-37 (discussing cases).

${ }^{28}$ Banking Act of 1933, Pub. L. No. 73-66, 48 Stat. 162 (codified as amended in scattered sections of 12 U.S.C.).

${ }^{29}$ Before the 2007-2008 financial crisis, the ceiling on deposit insurance was $\$ 100,000$ per depositor. On October 3, 2008, the Emergency Economic Stabilization Act (EESA) temporarily raised the basic limit to $\$ 250,000$, which was set to return to $\$ 100,000$ after December 31, 2009. Emergency Economic Stabilization Act of 2008, Pub. L. No. 110-343, § 136, 122 Stat. 3765, 3799. The DoddFrank Act made the $\$ 250,000$ ceiling permanent, as well as retroactive to January 1, 2008, in order to cover depositors at banks that failed early in the financial crisis before EESA's enactment. Dodd-Frank
} 
Deposit insurance has some undesirable side effects, though. Even with nonfinancial firms, which are less leveraged and not generally at risk of having to pay off their major liabilities on demand, a conflict exists between equity holders and creditors. As the finance canon has taught us, debt and equity generally hold differing risk preferences..$^{30}$ The flip side of shareholders' preference for risky bets at creditors' expense is creditors' preference for more conservative strategies. Creditors enjoy only a fixed upside - their interest payments and return of principal at a loan's maturity - and they enjoy a priority over equity in terms of repayment. ${ }^{31}$ Creditors would therefore rather the firm avoid the high-risk, potentially high-return bets that shareholders may prefer. ${ }^{32}$ High leverage generally magnifies this

Wall Street Reform and Consumer Protection Act, Pub. L. No. 111-203, § 335, 124 Stat. 1376, 1540 (2010).

${ }^{30}$ See Smith \& Warner, supra note 9, at 118.

31 In practice, this means that a firm must be solvent in order for the firm to make any distribution to equity holders, and that upon dissolution creditors are repaid in full before equity holders receive any distribution. MODEL BuS. CORP. ACT § 6.40(c) (2008) (requiring that in order to make a distribution to shareholders, the corporation must be solvent and able to pay its debts as they become due after giving effect to the distribution); $i d$. $\S 14.09$ (a) (requiring the directors to pay or provide for the payment of claims before making distributions of assets to shareholders).

32 See Jensen \& Meckling, supra note 1, at 333-34 (discussing the agency costs of debt versus equity).

A concrete example will illustrate. Assume a firm owes $\$ 90$ of debt, has $\$ 100$ in cash, and has two investment options for its $\$ 100$ in cash - a high-risk option and a low-risk option. The firm will pursue one of its investment options, and then, whatever the outcome, the firm will liquidate and distribute its assets to repay creditors, with shareholders receiving any residual.

The low-risk option has two possible outcomes:

(1) $60 \%$ chance of returning $\$ 110$, or

(2) $40 \%$ chance of returning $\$ 90$.

This low-risk option's expected value to the firm is $\$ 102((60 \% \times \$ 110)+(40 \% \times \$ 90))$. For its initial $\$ 100$ investment, the firm expects a net gain of $\$ 2$.

The firm's high-risk option has two possible outcomes:

(1) $10 \%$ chance of returning $\$ 1000$, or

(2) $90 \%$ chance of returning $\$ 0$.

This high-risk option's expected value to the firm is $\$ 100((10 \% \times \$ 1000)+(90 \% \times \$ 0))$. The firm expects no net gain from this investment.

The low-risk investment is clearly better for the firm and for creditors. Creditors will prefer the safer, low-risk investment because they will be repaid in full in any event. Whichever outcome occurs under the low-risk investment, the firm will still have at least $\$ 90$ to pay creditors. By contrast, with the high-risk investment, creditors face a $90 \%$ chance of being paid nothing.

Shareholders, however, will prefer the high-risk investment because its expected return to them is much higher than with the low-risk investment. Consider the distribution of value as between creditors and shareholders with the low-risk investment. The expected value of the $\$ 102$ return is shared $\$ 90$ to creditors $((60 \% \times \$ 90)+(40 \% \times \$ 90))$ and $\$ 12$ to shareholders $((60 \% \times \$ 20)+(40 \% \times \$ 0))$.

Now consider the distribution of returns from the high-risk investment. If the investment succeeds, creditors will be paid in full, receiving their $\$ 90$; if the investment fails, creditors will receive nothing. Because there is only a $10 \%$ likelihood of full payment to creditors, and a $90 \%$ chance they will receive nothing, their expected return is $\$ 9((10 \% \times \$ 90)+(90 \% \times \$ 0))$. Shareholders, on the other hand, expect to receive $\$ 91((10 \% \times \$ 910)+(90 \% \times \$ 0))$. 
debt-equity conflict and managers' risk-taking tendencies. ${ }^{33}$ The higher the leverage, the greater is the conflict. ${ }^{34}$

With banks, this agency cost of debt is even worse. Not only are banks highly leveraged, but their capital structures are not like those of ordinary (nonfinancial) firms. With ordinary firms, creditors - understanding firm managers' risk-taking predilections - bargain for constraints on risk taking and monitor compliance. ${ }^{35}$ In addition, excessive risk taking increases borrowing costs for ordinary firms. At the limit, a risky firm may not be able to borrow at any price. Banks, however, face a very different situation. Much of their borrowing takes the form of demand deposits from many small, widely dispersed customers. Because these customer-creditors enjoy deposit insurance, they do not impose the contractual or market constraints on bank risk taking that creditors would ordinarily impose on nonbanking firms. Insured depositors do not monitor or price their credit to account for insolvency or liquidity risk because FDIC insurance covers the risk. Bankers may shirk or steal $;{ }^{36}$ they may faithfully pursue wealth maximization for shareholders by extending risky, high-interest loans. In any event, insured depositors do not care. They are largely indifferent to bank risk taking, so they do not impose the constraints that creditors typically demand with nonfinancial firms.

The product market discipline that affects nonfinancial firms also does not operate well on banks. In a competitive market for deposit taking and other financial services, customers selecting a bank would care about bank

So even though the risky investment is worth less to the firm overall and is much worse for creditors in expected value terms, shareholders would push for the risky investment since its expected return to them of $\$ 91$ is much higher than their expected return of $\$ 12$ from the low-risk investment. More generally, because of their differing rights to the firm's returns, creditors and equity holders value investment opportunities differently, with creditors being more conservative and equity holders being more risk preferring.

${ }^{33}$ Id.; Teresa A. John \& Kose John, Top-Management Compensation and Capital Structure, 48 J. FIN. 949, 968 (1993).

34 The modern BHC structure, in which a holding company owns banks along with nonbank businesses as affiliates, intensifies this debt-equity conflict. The conflict is more severe because holding company equity holders are effectively subordinated to both the debt of the holding company and the debt of the banking subsidiary. See infra Part III.D.

${ }^{35}$ Banks, for example, play an important monitoring role to constrain their borrowers' risk taking. See Frederick Tung, Leverage in the Board Room: The Unsung Influence of Private Lenders in Corporate Governance, 57 UCLA L. REV. 115 (2009).

${ }^{36}$ Over three decades ago, Jensen and Meckling explained the agency conflicts that accompany outside investment in a firm. Once outside equity holders are brought in as investors and firm managers own less than all of the residual interests in the firm, managers have the incentive to shirk because they enjoy only a fraction of the benefits of their efforts. They must share with outside equity holders. "[A]s the manager's ownership claim falls, his incentive to devote significant effort to creative activities such as searching out new profitable ventures falls." Jensen \& Meckling, supra note 1, at 313. Shirking becomes a problem because monitoring of managerial effort by outside investors may not be easy. Id. at 328. 
solvency and would channel their deposits accordingly. ${ }^{37}$ Deposit insurance, however, blunts the effect of financial stability as a margin of competition among banks. ${ }^{38}$ Moreover, deposit insurance premiums are not finely calibrated to account for the particular risks posed by individual banks. ${ }^{39}$ Therefore, absent perfect regulatory oversight, bankers have an incentive to externalize losses to the insurance pool - and indirectly to the healthy banks that contribute to the insurance pool and the taxpayers that ultimately stand behind the pool. ${ }^{40}$

Finally, as with nonfinancial firms, bank managers' risk-taking incentives intensify as the bank nears insolvency. Note that insolvency is merely the extreme case of high leverage, where a firm's shareholders have nothing left to lose, and managers are effectively betting with creditors' money. As in the high-leverage scenario, managers intent on benefiting shareholders may pursue high-risk bets, even those with a negative expected value, to creditors' detriment. ${ }^{41}$ This problem is exacerbated with banks. A nonfinancial firm on the skids will run out of cash to invest. A bank, by contrast, can raise the cash to double down by continuing to borrow. By raising deposit interest rates, banks can continue to attract cash because of the government insurance. A troubled bank therefore does not suffer the same liquidity constraints that capital markets impose on nonfinancial companies in distress.

\section{Bank Risk Regulation}

Deposit insurance essentially substitutes the government for insured depositors as the major creditor of the bank. The government as creditor

\footnotetext{
37 The opacity of bank risk taking might as a practical matter preclude depositors and other unsophisticated outsiders from imposing market discipline on banks, even in the absence of deposit insurance. See Frederic S. Mishkin, Prudential Supervision: Why Is It Important and What Are the Issues?, in Prudential SuPervision 1, 8 (Frederic S. Mishkin ed., 2001). One could imagine, though, that in the absence of deposit insurance and government supervision private information intermediaries might emerge to meet depositors' demands for information on individual banks' risk taking.

${ }^{38}$ Financial stability is not wholly irrelevant to consumers, of course. Not all consumer financial products offered by banks are insured. FED. DEPOSIT INS. CORP., supra note 22. The same is true for deposit accounts in excess of the FDIC insured limit. See FED. DEPosit InS. CORP., DEPOSIT INSURANCE SUMMARY, http://www.fdic.gov/deposit/deposits/dis/index.html (last visited Aug. 2, 2011) (describing the FDIC insurance coverage limits).

39 See infra note 225 and accompanying text.

40 The FDIC maintains a deposit insurance fund with the insurance premiums collected from insured banks. FED. DEPOSIT INS. CORP., THE DEPOSIT INSURANCE FunD, http://www.fdic.gov/deposit/ insurance/index.html (last visited Sept. 28, 2011). The FDIC uses the fund to repay failed banks' depositors, but this repayment obligation does not depend on the solvency of the fund. FDIC insurance is backed by the full faith and credit of the United States government, FED. DEPOSIT INS. CORP., supra note 38, which means that taxpayers ultimately back the insurance obligation.

41 See Frederick Tung, The New Death of Contract: Creeping Corporate Fiduciary Duties for Creditors, 57 EMORY L.J. 809, 820-23 (2008) (explaining shareholder-wealth-maximizing managers' perverse incentives when the firm is at or near insolvency).
} 
has an economic interest in constraining excessive risk taking. Regulatory agencies and their bank examiners represent the government in this endeavor. Unlike private creditors of nonfinancial firms, however, regulators do not have their own money on the line. So while they possess significant expertise and enjoy important regulatory powers, they may lack the strong incentives of private lenders to efficiently monitor firms' management. Private lenders with their own money on the line will expend resources monitoring only to the point where the marginal cost of monitoring equals the marginal benefit. Government regulators do not have such finely honed incentives. The extent of their monitoring is politically determined. In some cases, their regulation and supervision may be excessive; in others, it may be insufficient. ${ }^{42}$ The prospect of regulatory capture of course also lurks. ${ }^{43}$

In addition to incentive problems, regulators may suffer from information deficits in the face of financial innovation. ${ }^{44}$ Innovation often transcends regulatory classifications or lines of regulatory authority, making it quite difficult for regulators to keep up. ${ }^{45}$ More generally, accurately quantifying the credit risk in a bank's loan portfolio is no simple task. ${ }^{46}$

Especially when an economy is booming, it may be difficult for regulators to rein in bank risk taking, ${ }^{47}$ which would curtail the supply of credit to profitable (or potentially profitable) enterprises. In good economic times, investors in firms and banks will want their firms to take risks and their banks to finance them, and they may incentivize managers to do so. The next Part explains the structure of bankers' incentive pay preceding the recent financial crisis and offers some historical context for performancebased pay for bankers.

\footnotetext{
${ }^{42}$ Regulatory forbearance may be an especially tricky problem. See infra notes $138-41$ and accompanying text.

43 See Howell E. Jackson, A Pragmatic Approach to the Phased Consolidation of Financial Regulation in the United States 23-24 (Harvard Law Sch. Pub. Law \& Legal Theory Working Paper Series, Paper No. 09-19, 2008), available at http://ssrn.com/abstract=1300431 (discussing regulatory capture in the financial services industry).

${ }^{44}$ Charles K. Whitehead, Reframing Financial Regulation, 90 B.U. L. REV. 1, 33 (2010); Henry T.C. Hu, Misunderstood Derivatives: The Causes of Informational Failure and the Promise of Regulatory Incrementalism, 102 YALE L.J. 1457, 1463 (1993) (reviewing PETER L. BERNSTEIN, CAPITAL IDEAS: THE IMProbable ORIGiNS OF MODERN WALL STREet (1992)) (noting the consensus that "regulatory informational failure" is a serious impediment to effective financial regulation).

${ }^{45}$ Henry T.C. Hu, Swaps, the Modern Process of Financial Innovation and the Vulnerability of a Regulatory Paradigm, 138 U. PA. L. REV. 333, 399 (1989) (describing the fragmentation of legal and political authority that makes regulation difficult in the face of financial innovation).

${ }^{46}$ See infra text accompanying note 224.

47 See Raghuram Rajan, Cycle-Proof Regulation, ECONOMIST, Apr. 11, 2009, at 79, available at http://www.economist.com/businessfinance/displayStory.cfm?story_id=13446173.
} 


\section{PAY FOR PERFORMANCE AND THE FINANCIAL CRISIS}

Commentators have decried the role of perverse managerial incentives in precipitating the financial crisis. ${ }^{48}$ As a prelude to the detailed presentation of my proposal, this Part offers a short history of banker pay for performance leading up to the crisis. Two parallel decades-long trends-the steady march of banking deregulation and the rise of equity-based performance pay generally-help to explain the evolution toward the highpowered equity incentives for bankers that we observe pre-crisis.

For bank managers, standard equity-based incentive pay may encourage excessive risk taking that is inimical to the public interest in bank safety and soundness. Aligning managers' interests more closely with those of bank equity holders exacerbates the moral hazard that accompanies deposit insurance. It gives bankers a personal stake in the unlimited upside that they might potentially enjoy from high-risk, high-return strategies ${ }^{49}$-an approach that bank regulators typically wish to discourage. ${ }^{50}$

An understanding of how we arrived at this state of affairs offers useful context for formulating policy going forward.

\section{A. Pay for Performance for Shareholders}

Standard corporate governance arrangements such as fiduciary duties and shareholder voting are generally designed to align managers' decisionmaking with the interests of the firm's equity holders, ${ }^{51}$ who are generally viewed as the firm's "owners." 52 Similarly, pay for performance - typically in the form of equity or equity-based options - intends to overcome manag-

48 See, e.g., Judith F. Samuelson \& Lynn A. Stout, Opinion, Are Executives Paid Too Much?, WALL ST. J., Feb. 26, 2009, at A13 (decrying the role of badly designed executive compensation plans in encouraging the managerial "short-termism" that led to the financial crisis); Press Release, Bd. of Governors of the Fed. Reserve Sys., supra note 3.

49 Kose John \& Yiming Qian, Incentive Features in CEO Compensation in the Banking Industry, FRBNY ECON. POL'Y REV., Apr. 2003, at 109, 110 (“[H]igher pay-performance sensitivity in management compensation aggravates the well-known risk-shifting incentives associated with risky debt.”).

50 One set of commentators even argues that pay-performance sensitivity should be accounted for in the pricing of deposit insurance. See John, Saunders \& Senbet, supra note 21.

51 Jonathan Macey and Maureen O'Hara have suggested broadening fiduciary duties for bank directors to include creditors along with shareholders as beneficiaries. In particular, they propose that bank directors consider solvency risk "explicitly and systematically" in their decisionmaking, upon pain of personal liability for failing to do so. Jonathan R. Macey \& Maureen O'Hara, The Corporate Governance of Banks, FRBNY ECON. POL'Y REV., Apr. 2003, at 91, 92. This approach may be problematic, however. Duties to multiple constituents may render bank managers accountable to no one. See Jonathan R. Macey, An Economic Analysis of the Various Rationales for Making Shareholders the Exclusive Beneficiaries of Corporate Fiduciary Duties, 21 STETSON L. REV. 23, 31-36 (1991) (arguing that other constituency statutes merely render managers accountable to no one). More generally, corporate duties seem to be a rather blunt device for regulating risk taking and may invite 20/20 hindsight litigation in the aftermath of a bank failure.

52 N. Am. Catholic Educ. Programming Found. v. Gheewalla, 930 A.2d 92, 101 (Del. 2007) (referring to shareholders as the "owners" of the corporation). 
ers' shirking and risk aversion in order to align their incentives with shareholders' more risk-preferring interests. ${ }^{53}$

The pay-for-performance movement of the 1990s led boards of directors and their compensation consultants to adopt equity-based compensation schemes. ${ }^{54}$ Tax code changes abetted this trend. ${ }^{55}$ As a result of these changes,${ }^{56}$ the percentage of executive compensation in the form of equity jumped from $37 \%$ in 1993 to $55 \%$ in 2003 for the top five executives of the S\&P 500 firms. ${ }^{57}$ Pay-performance sensitivity for CEOs - typically measured by the change in CEO wealth for every $\$ 1000$ change in shareholder wealth ${ }^{58}$-increased more than tenfold between 1980 and $1999 .{ }^{59}$

Consistent with the finance canon, however, a greater managerial focus on improving shareholder returns means riskier investment strategies that place more risk on creditors. ${ }^{60}$ Whether pay for performance has been gen-

${ }^{53}$ Managers with firm-specific human capital investments in their firm might be reluctant to pursue risky but potentially profitable projects. Their undiversifiable human capital investments make them imperfect agents for diversified shareholders. FRANK H. EASTERBROOK \& DANIEL R. FisCHEL, THE ECONOMiC Structure OF CoRporate LAW 99-100 (1991); M. Todd Henderson, Paying CEOs in Bankruptcy: Executive Compensation When Agency Costs Are Low, 101 Nw. U. L. REV. 1543, 1549 (2007). With only fixed compensation, managers may also be tempted to build empires, since pay is typically associated with firm size. Henderson, supra.

54 See, e.g., Lucian Bebchuk \& Jesse Fried, Pay Without Performance: The Unfulfilled Promise of EXecutive Compensation 1 (2006); Bengt Holmstrom \& Steven N. Kaplan, The State of U.S. Corporate Governance: What's Right and What's Wrong?, J. APPLIED CoRP. Fin., Spring 2003, at 8,12 (describing the rise of equity-based pay from the 1980s to the 1990s).

55 Since 1994, only the first million dollars of non-performance-based compensation for public company executives is deductible. I.R.C. $\S 162(\mathrm{~m})$ (2006). Ironically, these tax law changes were intended to curb total executive pay, but this plan has not worked out as intended. See Gregg D. Polsky, Controlling Executive Compensation Through the Tax Code, 64 WASH. \& LEE L. REV. 877, 916-20 (2007) (arguing that $\S 162(\mathrm{~m})$ has led to higher executive compensation and lower shareholder wealth, contrary to its original intent).

${ }^{56}$ Evidence suggests that the enactment of $\S 162(\mathrm{~m})$ has reduced salaries and increased payperformance sensitivity. See Tod Perry \& Marc Zenner, Pay for Performance? Government Regulation and the Structure of Compensation Contracts, 62 J. FIN. ECON. 453, 456 (2001).

${ }^{57}$ Lucian Bebchuk \& Yaniv Grinstein, The Growth of Executive Pay, 21 OXFORD REV. ECON. POL'Y 283, 289, 290 tbl.4 (2005).

58 See Michael C. Jensen \& Kevin J. Murphy, Performance Pay and Top-Management Incentives, 98 J. POL. ECON. 225, 226 (1990) (applying the typical pay-performance sensitivity analysis).

59 Holmstrom \& Kaplan, supra note 54, at 12.

${ }^{60}$ See supra note 32 and accompanying text; see also Jensen \& Meckling, supra note 1, at 336 (explaining owner's incentive to shift risk to bondholders and redistribute wealth from them to himself). One study found, for example, that bond return premiums increase with managerial ownership. See Elizabeth Strock Bagnani et al., Managers, Owners, and the Pricing of Risky Debt: An Empirical Analysis, 49 J. FIN. 453, 454 (1994) (finding that among Fortune 500 companies managerial ownership of between $5 \%$ and $25 \%$ is associated with higher bond return premiums). Bondholders understand that managers more closely aligned with shareholder interests will tend to adopt riskier investment strategies in pursuit of higher shareholder returns. Because this increases risk to bondholders, rational bondholders demand higher premiums for this risk. $I d$. at $455-56$. 
erally good for shareholders is the subject of some debate. ${ }^{61}$ Nonetheless, compensation for bank officers before the financial crisis tracked the same basic shareholder-based incentive framework, and managers' equity stakes have been shown to be significantly correlated with bank returns and risk. ${ }^{62}$

\section{B. The Evolution of Incentive Pay for Bankers}

Banking deregulation and performance incentives for bank management have more or less gone hand in hand since the late 1970s. This is consistent with more general empirical and theoretical work showing an inverse relation between regulation and pay-performance sensitivity. ${ }^{63}$ Within and across regulated industries, regulation has been associated with lower pay-performance sensitivity in executive compensation, ${ }^{64}$ and payperformance sensitivity has generally increased with deregulation. ${ }^{65}$

A prevailing agency theory explanation is that deregulation facilitates competition, and that this competition creates growth opportunities within the deregulated industry and increases managerial discretion. ${ }^{66}$ In this environment, investors may prefer to offer managers more powerful performance incentives for risk taking in pursuit of these new growth opportunities. ${ }^{67}$ At the same time, greater growth options make monitoring

\footnotetext{
${ }^{61}$ For critical views, see BEBCHUK \& FRIED, supra note 54, at 121-22, which argues that corporate governance failures have enabled managers to enrich themselves under the guise of pay for performance, and Charles M. Yablon, Overcompensating: The Corporate Lawyer and Executive Pay, 92 Colum. L. ReV. 1867, 1888 (1992), which reviews Graef Crystal, In SEARCH OF EXCESS (1991) and considers the difficulties of implementing effective pay for performance.

${ }^{62}$ See Anthony Saunders et al., Ownership Structure, Deregulation, and Bank Risk Taking, 45 J. FIN. 643, 653 (1990) (finding a positive association between bank risk taking and managerial stock ownership); see also Fahlenbrach \& Stulz, supra note 5 (finding some evidence that better alignment of CEO incentives with shareholder interests has been associated with worse firm performance in the credit crisis).

${ }^{63}$ See supra notes 58-60 and accompanying text.

${ }^{64}$ See, e.g., Paul Joskow et al., Regulatory Constraints on CEO Compensation, BROOKINGS PAPERS ON ECON. ACTIVITY: MicROECONOMICS, no. 1, 1993, at 1, 2-3 (showing lower levels of CEO pay and lower pay-performance sensitivity for regulated firms than for unregulated firms); Clifford W. Smith, Jr. \& Ross L. Watts, The Investment Opportunity Set and Corporate Financing, Dividend, and Compensation Policies, 32 J. Fin. ECON. 263 (1992) (using industry-level data from 1965 to 1985 to show that firms in regulated industries - insurance, banking, and gas and electric utilities-have lower executive compensation than those in unregulated industries and make less use of stock and bonus plans).

${ }^{65}$ See R. Glenn Hubbard \& Darius Palia, Executive Pay and Performance: Evidence from the U.S. Banking Industry, 39 J. FIN. ECON. 105 (1995) (finding a positive association between bank CEO pay and firm performance in the 1980s and a stronger association in deregulated markets); see also Stacey R. Kole \& Kenneth M. Lehn, Deregulation and the Adaptation of Governance Structure: The Case of the U.S. Airline Industry, 52 J. FIN. ECON. 79, 100 (1999) (finding that the value of airline CEO stock option grants increased after deregulation and that this impact of deregulation increased over time).

${ }^{66}$ See Smith \& Watts, supra note 64, at 274-76.

${ }^{67}$ See Vicente Cuñat \& Maria Guadalupe, Executive Compensation and Competition in the Banking and Financial Sectors, 33 J. BANKING \& FIN. 495, 496 (2009); Michael Raith, Competition, Risk, and Managerial Incentives, 93 AM. ECON. REV. 1425, 1432 (2003).
} 
more difficult for outsider directors and shareholders, so incentive compensation is relied upon to bond managers to shareholder interests. ${ }^{68}$ In the banking industry, deregulation has led to significant increases in growth opportunities, so it makes sense that increased pay-performance sensitivity accompanied the deregulation that occurred over the last four decades.

States began to deregulate intrastate branching and interstate banking in the late 1970s. ${ }^{69}$ Before this deregulation, commercial banking was a relatively clubby, cozy business, with banks operating in fairly protected, geographically segmented markets. ${ }^{70}$ Not only was interstate banking prohibited, ${ }^{71}$ but also most states limited the size and geographical scope of banks operating within their borders. ${ }^{72}$ These constraints effectively limited the territorial scope of competition, carving up banking markets within each state. At the start of banking deregulation, only twelve states allowed unrestricted branching. ${ }^{73}$ However, by 1990 , thirty-eight states and the District of Columbia had removed all intrastate branching restrictions. ${ }^{74}$

${ }^{68}$ Smith \& Watts, supra note 64, at 275-76; see Jonathan Eaton \& Harvey S. Rosen, Agency, Delayed Compensation, and the Structure of Executive Remuneration, 38 J. FIN. 1489, 1498 (1983) (explaining that firms prefer to incentivize executives with stock options when the executives enjoy wide discretion and are difficult to monitor).

69 Anthony J. Crawford et al., Bank CEO Pay-Performance Relations and the Effects of Deregulation, 68 J. BUS. 231, 233 (1995) (noting that most states required reciprocity); see also Hubbard \& Palia, supra note 65, at 109 (describing state-level deregulation of interstate banking beginning in the early 1980s).

${ }^{70}$ Consistent with agency theory, incentive pay was small relative to fixed compensation. Growth opportunities were relatively few, so there was little need to spur risk taking with incentive compensation. See, e.g., Crawford et al., supra note 69, at 236, 241 (finding no statistically significant relation between CEO salary and bonus and shareholder wealth and no statistically significant pay-performance sensitivity of CEO option holdings prior to deregulation); Joel F. Houston \& Christopher James, CEO Compensation and Bank Risk: Is Compensation in Banking Structured to Promote Risk Taking?, 36 J. MONETARY ECON. 405, 407 (1995) (finding lower bank CEO stock holdings and less reliance on optionbased compensation than in other industries, reflecting differences in investment opportunities, for banks from 1980 to 1990). This all changed with deregulation, which brought increased competition to commercial banking, as well as more performance-based pay for bank executives and increased payperformance sensitivity. See Hubbard \& Palia, supra note 65, at 108 (noting that increased competition from bank deregulation requires a more capable CEO and higher and more responsive pay). See generally Crawford et al., supra note 69 (investigating bank CEO compensation from 1976 to 1988); Cuñat \& Guadalupe, supra note 67 (testing effects of banking deregulation from 1992 to 2002); Hubbard \& Palia, supra note 65 (examining bank CEO pay in the 1980s).

${ }^{71}$ States enjoyed the power to block interstate banking under the Douglas Amendment to the Bank Holding Company Act of 1956, which barred a BHC from acquiring a bank outside its home state without the approval of the target bank's state. 12 U.S.C. §1842(d) (2006).

${ }^{72}$ Kevin J. Stiroh \& Philip E. Strahan, Competitive Dynamics of Deregulation: Evidence from U.S. Banking, 35 J. MONEY, CREDIT \& BANKING 801, 806 (2003). In "unit" banking states, branching was strictly prohibited. In effect, each bank was permitted only one place of business - its unit bank-within the state. Other states allowed only limited branching. Id.

${ }^{73} \mathrm{Id}$.

74 Id. at 808 tbl.1. 
Interstate banking received a boost at the federal level in 1982: an amendment to the Bank Holding Company $\mathrm{Act}^{75}$ sanctioned interstate acquisition of failed banks and thrifts regardless of state law. ${ }^{76}$ Many states responded to the Act by entering into reciprocal multistate agreements freely allowing bank acquisitions among participant states. By 1989, forty-four states and the District of Columbia allowed some interstate banking. ${ }^{77}$

Continuing this trend, the Riegle-Neal Act (RNA) formally unleashed interstate banking across all states in $1994 .{ }^{78}$ Then in 1999, the GrammLeach-Bliley Financial Services Modernization Act (GLB Act) formally repealed the Depression-era barriers among banking, insurance, and securities activities. ${ }^{79}$ This allowed the formation of multiline financial services firms in the form of bank holding companies. ${ }^{80}$ These important deregulatory statutes pushed commercial banks further out of their cozy protected markets, ${ }^{81}$ forcing them not only to compete with one another across state lines $^{82}$ but also to compete with diversified financial firms with insurance and securities businesses as well as traditional commercial banking.

\footnotetext{
7512 U.S.C. $\$ 1842$.

${ }^{76}$ Garn-St. Germain Depository Institutions Act (Garn-St. Germain Act) of 1982, Pub. L. No. $97-$ $320, \S 116,96$ Stat. 1469, 1476-79 (codified at 12 U.S.C. § 1823); see also Randall S. Kroszner \& Philip E. Strahan, What Drives Deregulation? Economics and Politics of the Relaxation of Bank Branching Restrictions, 114 Q.J. ECON. 1437, 1442 (1999) (describing the impact of the Garn-St. Germain Act). The range of permissible products that depository institutions could offer was broadened beginning in 1980. For example, DIDMCA preempted state usury laws capping mortgage interest rates, finance charges, and discount points. DIDMCA, Pub. L. No. 96-221, § 501, 94 Stat. 161, 161-63 (codified at 12 U.S.C. $\S 1735 \mathrm{f}-7 \mathrm{a}$ ). The Garn-St. Germain Act authorized depository institutions to offer money market deposit accounts. Garn-St. Germain Act $\$ 327$ (codified at 12 U.S.C. § 3503) (directing the Deposit Institutions Deregulation Committee to promulgate rules allowing depository institutions to offer a new deposit account "directly equivalent to and competitive with money market mutual finds"). The GarnSt. Germain Act also preempted state law restrictions on due-on-sale clauses. Garn-St. Germain Act $\S 341$ (codified at 12 U.S.C. $\S 1701 \mathrm{j}-3(\mathrm{~b})(1)$ ).

77 Stiroh \& Strahan, supra note 72, at 808 tbl.1.

78 Riegle-Neal Interstate Banking and Branching Efficiency Act of 1994, Pub. L. No. 103-328, 108 Stat. 2338 (codified in scattered sections of 12 U.S.C.).

79 Gramm-Leach-Bliley Act, Pub. L. No. 106-102, § 101, 113 Stat. 1338, 1341 (1999).

${ }^{80} \mathrm{Id}$. Before the GLB Act, BHC structures were permitted through the regulatory discretion of federal banking regulators. Jonathan R. Macey, The Business of Banking: Before and After GrammLeach-Bliley, 25 J. CORP. L. 691, 692 (2000). Perhaps the most significant effect of the GLB Act was to allow investment banks to acquire commercial banks. Id. at 694 . Commercial banks were already being allowed by regulators to acquire investment banking operations by the time of the GLB Act's passage. Id.

${ }^{81}$ See Cuñat \& Guadalupe, supra note 67, at 497.

82 On the heels of the RNA, the total number of bank branches per capita in the United States increased, as did the average number of banks operating at the state level and the average number of states in which a bank operated. See Astrid A. Dick, Nationwide Branching and Its Impact on Market Structure, Quality, and Bank Performance, 79 J. Bus. 567, 585 (2006).
} 
Deregulation had salutary procompetitive effects, ${ }^{83}$ and empirical studies bear out the agency theory predictions for banker compensation discussed earlier. Increased competition led to greater growth opportunities in commercial banking, and shareholders wished to incentivize their managers to pursue these opportunities. ${ }^{84}$ Pay-performance sensitivity for bank CEOs increased significantly. ${ }^{85}$

Studies show that bank managers performed better with higher insider stock ownership in the 1980 s, especially in deregulated markets. ${ }^{86}$ Consistent with agency theory, however, and borne out by subsequent experience in the recent financial crisis, studies of past deregulatory periods show that risk taking may also be exacerbated in less regulated markets when bank directors and officers own large equity stakes, ${ }^{87}$ especially when the banks are under financial stress. ${ }^{88}$

${ }^{83}$ The costs and pricing of banking services fell. See Jith Jayaratne \& Philip E. Strahan, Entry Restrictions, Industry Evolution, and Dynamic Efficiency: Evidence from Commercial Banking, 41 J.L. \& ECON. 239, 249-53 (1998). States that dismantled intrastate branching restrictions saw faster growth after deregulation. See Jith Jayaratne \& Philip E. Strahan, The Finance-Growth Nexus: Evidence from Bank Branch Deregulation, 111 Q.J. ECON. 639, 639 (1996). Interstate competition also led to reallocation of assets to more efficient banks. See Stiroh \& Strahan, supra note 72, at 804.

${ }^{84}$ Crawford et al., supra note 69 , at 232-33.

${ }^{85} \mathrm{Id}$. at 232 (finding significant increases in pay-performance sensitivity changes as to salary plus bonus, stock options, and stock ownership between 1976 and 1988); Cuñat \& Guadalupe, supra note 67, at 496-97 (investigating the 1992 to 2002 period); Elijah Brewer III et al., Deregulation and the Relationship Between Bank CEO Compensation and Risk-Taking 20-21 (Fed. Reserve Bank of Chi. Working Paper No. 2003-32, 2003), available at http://ssrn.com/abstract=486985 (finding a significant increase in the equity-based component of executive pay following the RNA).

For example, relative to other financial company executives, following the passage of the RNA, commercial bank executives enjoyed an additional 36\& increase in option value for every $\$ 1000$ increase in shareholder value. Cuñat \& Guadalupe, supra note 67, at 503. After the GLB Act's passage, payperformance sensitivity for financial executives' total pay saw a marginal increase of $24 \%$ relative to executive pay in nonfinancial service sectors, which amounted to an additional $6 \notin$ in total pay for every dollar increase in shareholder wealth. Id. at 502. While total pay increased only marginally with the 1990s deregulation, its composition changed dramatically. Total fixed compensation fell, but incentive pay rose, becoming a larger share of total pay. Id. at 501-02. To test for the effects of the RNA, Cuñat and Guadalupe compared bank executive compensation with a control group of other financial companies both before and after bank deregulation. Id. at 497. With respect to the GLB Act, they compared financial sector executive compensation with the compensation of executives in the remaining service sectors in the economy. Id. at 498.

Crawford and his coauthors also found some evidence that CEO pay-performance sensitivity increased more at less well-capitalized banks after deregulation, suggesting more severe moral hazard problems at these riskier banks. Crawford et al., supra note 69, at 233.

${ }^{86}$ Rebel A. Cole \& Hamid Mehran, The Effect of Changes in Ownership Structure on Performance: Evidence from the Thrift Industry, 50 J. FIN. ECON. 291, 301-15 (1998) (measuring stock returns for publicly traded thrifts that converted from mutual to stock ownership from 1983 to 1987); Hubbard \& Palia, supra note 65, at 108.

${ }^{87}$ Ronald C. Anderson \& Donald R. Fraser, Corporate Control, Bank Risk Taking, and the Health of the Banking Industry, 24 J. BANKING \& FIN. 1383, 1384 (2000) (finding a positive association between management shareholdings and greater bank-specific risk during the late 1980s, when banks were relatively less regulated and the industry was under stress); Saunders et al., supra note 62, at 653 (find- 


\section{Banker Pay Preceding the Crisis}

By the time of the financial crisis, the incentive pay structure for bankers had come to resemble the standard shareholder-wealth-maximizing approach to compensation used in unregulated industries. Bankers' pay immediately before the crisis was substantial and mostly performance based. It was also more equity-laden relative to inside debt than was pay at nonfinancial firms.

At the end of 2006, total BHC CEO pay averaged $\$ 7.8$ million, and less than $10 \%$ of it was in the form of fixed salary. ${ }^{89}$ The rest was performance based. ${ }^{90}$ Equity-based compensation accounted for just over half of total CEO pay on average. ${ }^{91}$ Perhaps more importantly, in addition to annual compensation, these CEOs already held large equity stakes in their firms. Given their size, these equity portfolios generally have much stronger incentive effects than annual compensation. ${ }^{92}$ The average BHC CEO's equity portfolio was worth $\$ 87.5$ million in 2006 , over ten times larger than the CEO's total annual compensation and over twenty times larger than the value of annual equity-based compensation..$^{93}$ The average BHC CEO's share holdings amounted to $1.6 \%$ of the firm's outstanding shares. ${ }^{94}$ The

ing greater risk taking in publicly traded banking organizations during the 1979 to 1982 period of relative deregulation when managers held larger equity stakes).

${ }^{88}$ Cf. Anderson \& Fraser, supra note 87, at 1397.

${ }^{89}$ Fahlenbrach \& Stulz, supra note 5, at 16 tbl.3.

90 Id. at 15-16. Performance-based pay in Fahlenbrach and Stulz's study includes both equitybased compensation and cash bonuses for performance achievements. Their sample, constructed from financial firms with compensation data in Standard and Poor's ExecuComp database, is dominated by large banks, though a few securities firms are also included. $I d$. at 14, 25 app.A.2. The median firm has assets worth $\$ 15.5$ billion, and the mean asset value is $\$ 129.3$ billion. Id. at 14 .

${ }^{91} I d$. at 16 tbl.3 (showing the average CEO's total compensation to be almost $\$ 7.8$ million, with average annual stock compensation of $\$ 2.65$ million and average annual option compensation of $\$ 1.61$ million).

92 See John Core \& Wayne Guay, The Use of Equity Grants to Manage Optimal Equity Incentive Levels, 28 J. ACCT. \& ECON. 151, 152 (1999) (explaining the importance of portfolio incentives and showing that firms structure annual equity grants to optimize managers' portfolio incentives); Brian J. Hall \& Jeffrey B. Liebman, Are CEOs Really Paid Like Bureaucrats?, 113 Q.J. ECON. 653, 654 (1998) (finding a strong relationship between pay and performance for public company CEOs from 1980 to 1994 and that virtually all pay-performance sensitivity was attributable to changes in the value of CEOs' equity portfolios).

93 Fahlenbrach \& Stulz, supra note 5, at 16 tbl.3. Twenty-one of the ninety-five CEOs in the sample held equity stakes in their firms worth more than $\$ 100$ million. Richard Fuld's equity stakes in Lehman Brothers exceeded \$911 million; James Caynes of Bear Stearns held equity stakes in his firm exceeding $\$ 1$ billion. Id. at 17 .

${ }^{94} I d$. at 16 tbl.3. Including delta-weighted options, the CEO's ownership share increased to $2.4 \%$. That is, for every $\$ 1000$ increase in shareholder wealth, the CEO's wealth would increase by $\$ 24$. Id. at 17. By comparison, John and Qian found average annual CEO share holdings of $1.38 \%$ in a sample of over 600 CEO-years for commercial banks from 1992 to 2000. John \& Qian, supra note 49, at 112 tbl.1. 
median BHC CEO also held more equity, less inside debt, and more equity relative to inside debt than the median CEO for nonfinancial firms. ${ }^{95}$

Pay statistics mid-crisis are consistent with this picture. As of June 2008 - in the lull between Bear Stearns's collapse in March and the traumatic few weeks of September when Lehman Brothers filed for bankruptcy and Fannie Mae, Freddie Mac, and AIG were taken over by the government $^{96}$ - BHC CEO compensation remained equity-fueled and generous. Among twenty-four of the largest bank holding companies, annual CEO compensation ranged as high as $\$ 73$ million, with ten CEOs making in excess of $\$ 10$ million. $^{97}$ As shown in Figure 1, CEOs of seventeen of these BHCs received over half of their total compensation in the form of incentive pay. ${ }^{98}$ The average percentage of incentive pay for the group was $61.4 \%$ of total compensation, with the median at $70.5 \%$.

FIGURE 1

\section{BANK CEO PERCENTAGE INCENTIVE COMPENSATION, JUNE 2008}

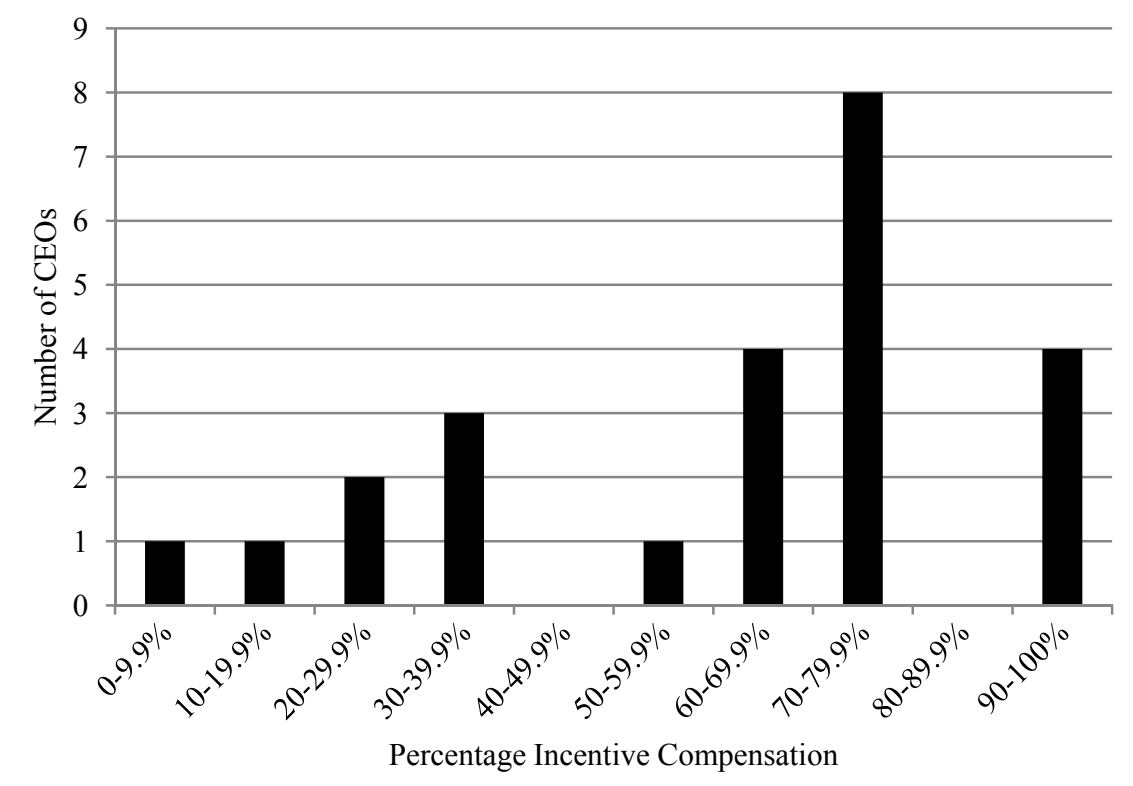

95 Tung \& Wang, supra note 14 , at 21.

96 Douglas W. Diamond \& Anil K. Kashyap, The F.A.Q.'s of Lehman and A.I.G.: A Guest Post, FREAKONOMICS BLOG (Sept. 18, 2008, 10:04 AM), http://www.freakonomics.com/2008/09/18/diamondand-kashyap-on-the-recent-financial-upheavals.

97 Richard Shaw, Bank Executive Compensation and the Bailout, SEEKING ALPHA (July 20, 2008), http://seekingalpha.com/article/85806-bank-executive-compensation-and-the-bailout (citing data from The Corporate Library, June 2008). The bank holding companies were the constituents of Keefe Bruyette \& Woods's Large Bank Index as of June 2008. Id.

98 Id. 


\section{Post-Crisis Pay Constraints}

Though bank regulators have enjoyed the explicit authority to regulate bankers' pay in order to guard against excessive risk taking since 1991, ${ }^{99}$ this authority was seldom used before the financial crisis and never targeted at the large money center banks that have been the focus of the financial crisis. ${ }^{100}$ With its Troubled Asset Relief Program (TARP) ${ }^{101}$ the Treasury Department attempted to rein in some of the perceived excess at firms receiving TARP aid, though TARP rules only vaguely addressed the perverse risk-taking incentives at work.

These rules imposed both corporate governance changes and substantive constraints on pay structure, including prohibitions on golden parachute payments and on compensation that encourages "unnecessary and excessive risks." ${ }^{102}$ In addition, the Treasury Department appointed Kenneth Feinberg to serve as a special master to oversee pay packages at TARP recipient in-

99 The Federal Deposit Insurance Corporation Improvement Act (FDICIA) of 1991, 12 U.S.C. $\S 1831 \mathrm{p}-1(\mathrm{c})(1)(\mathrm{A})$ (2006), empowers regulators to take enforcement action against compensation practices that might be unsafe or unsound banking practices, see infra note 220 and accompanying text, including not only compensation that is excessive but also compensation that creates incentives for excessive risk taking. Heidi Mandanis Schooner, Who Determines When Enough Is Enough? Refocusing Regulatory Limitations on Banks' Compensation Practices, 37 B.C. L. REV. 861, 867-68 (1996). Even before 1991, regulators might deem excessive compensation an unsafe or unsound banking practice. See infra note 220 .

100 At one level, this historical lack of intervention is not surprising. When institutions are profitable and the economy is growing, regulatory tinkering with executive compensation is politically difficult. Others have noted these cyclicality problems and called for countercyclical approaches to regulation. See, e.g., Rajan, supra note 47, at 79. As this financial crisis has taught us, bank executive compensation is an especially important place to start thinking about countercyclical regulation.

101 In the immediate aftermath of government takeovers at Fannie Mae, Freddie Mac, and AIG and the bankruptcy of Lehman Brothers, Congress passed the Emergency Economic Stabilization Act (EESA) in October 2008. Pub. L. No. 110-343, 122 Stat. 3765 (2008). EESA authorized the Treasury Department to spend $\$ 700$ billion to shore up the nation's financial system, pursuant to which the Treasury Department devised TARP. The following February, Congress enacted the American Recovery and Reinvestment Act of 2009 (ARRA), Pub. L. No. 111-5, 123 Stat. 115, which amended EESA by imposing significant new restrictions on executive compensation for firms receiving TARP financial assistance. Pursuant to ARRA authorization, both the Treasury Department and the Securities and Exchange Commission promulgated rules implementing ARRA's executive compensation restrictions.

102 ARRA $\S 7001$ (describing executive compensation limits). A golden parachute is a generous severance arrangement. The rules also limit bonus payments, retention awards, and incentive compensation to CEOs and other highly compensated employees. TARP Standards for Compensation and Corporate Governance, 74 Fed. Reg. 28,394 (June 15, 2009). For example, incentive compensation is required to be in the form of restricted stock that does not vest until government loans are repaid. Id. at 28,401. Tax gross-ups for highly compensated employees are also prohibited. Id. at 28,402. With a tax grossup, the employer firm covers its employee's income tax liabilities relating to her compensation. The rules also require that the firm's compensation committee conduct a semiannual review of employee compensation plans to assess the risks posed to the institution. Id. at 28,403. 
stitutions. ${ }^{103}$ Feinberg slashed cash salaries in favor of long-term stock grants. ${ }^{104}$

The Federal Reserve proposed much broader but similarly structured oversight of all incentive compensation arrangements at all of its regulated institutions $^{105}$ and not just TARP recipients. Most recently, Congress enacted the Dodd-Frank Act, legislating new regulatory attention to financial institutions' incentive pay arrangements. ${ }^{106}$ Pursuant to the Act, banking regulators issued guidelines for financial institutions prohibiting incentive pay arrangements that encourage inappropriate risk and requiring new disclosures concerning the structure of incentive pay. ${ }^{107}$

${ }^{103}$ Feinberg's primary role is to monitor compensation practices at firms receiving "exceptional financial assistance," namely AIG, Bank of America, Citigroup, General Motors Co., GMAC Inc., Chrysler Group LLC, and Chrysler Financial. Recently, he nixed the multimillion-dollar pay package of Ken Lewis, the retiring CEO of Bank of America, and slashed the salaries of hundreds of other employees in these seven firms. Deborah Solomon \& Dan Fitzpatrick, Pay Slashed at Bailout Firms, WALL ST. J, Oct. 22, 2009, at A1.

${ }^{104}$ Steven Brill, What's a Bailed-Out Banker Worth?, N.Y. TIMES, Jan. 3, 2009, § MM, at 32, 34; Solomon \& Fitzpatrick, supra note 103 (describing cash salary cap of $\$ 500,000$ and the use of "salary stock" that cannot be sold for at least four years). Recently, Feinberg approved a plan to pay AIG executives with "long term performance units," whose value depends $80 \%$ on the market value of AIG's junior debt and $20 \%$ on its common stock value. Serena Ng, AIG Changes Pay Plan for Its Stars, WALL ST. J., June 24, 2010, at C1. Unlike my proposal, the purpose of Feinberg's debt-based compensation is not to reduce executives' risk taking but rather to insulate their compensation from the volatility of AIG's stock price. Id.

105 Proposed Guidance on Sound Incentive Compensation Policies, 74 Fed. Reg. 55,227 (Oct. 27, 2009). Bank holding companies are the major institutions regulated by the Federal Reserve. The largest banks are owned by bank holding companies. According to the proposed guidance, incentive compensation at banking organizations should:

- Provide employees incentives that do not encourage excessive risk-taking beyond the organization's ability to effectively identify and manage risk;

- Be compatible with effective controls and risk management; and

- Be supported by strong corporate governance, including active and effective oversight by the organization's board of directors.

Id. at 55,228. Concurrent with its issuance of this new guidance on compensation, the Federal Reserve announced a supervisory initiative to review pay practices at all of its regulated entities. Id. at 55,229.

The G-20 group of important industrial and developing countries has also endorsed a set of compensation guidelines for financial institutions issued by the Financial Stability Board, a coalition of national financial authorities and international financial institutions. FIN. STABILITY BD., FSB PRINCIPLES FOR SOUND COMPENSATION PRACTICES: IMPLEMENTATION STANDARDS (2006), available at http://www.financialstabilityboard.org/publications/r_090925c.pdf.

106 Dodd-Frank Wall Street Reform and Consumer Protection Act, Pub. L. No. 111-203, § 956, 124 Stat. 1376, 1905-06 (2010). In addition to bankers' pay, the Dodd-Frank Act imposed significant new rules on public company executive compensation generally, requiring among other things "say on pay"- a shareholder vote on executives' compensation and any golden parachute arrangements, $i d$. $\S 951$; compensation committee independence and direct responsibility over compensation consultants, $i d$. $\$ 952$; and clawback provisions relating to incentive compensation awarded based on erroneous accounting later required to be restated for material noncompliance with financial reporting requirements, id. $\S 954$.

107 Guidance on Sound Incentive Compensation Policies, 75 Fed. Reg. 36,395 (June 25, 2010). 
While these government efforts constrain or prohibit certain pay practices felt to be most egregious in terms of enabling either too much pay or excessive risk taking, many of the prescriptions are vague, and on the whole, they lack a positive theory for what banker pay should look like. The next Part discusses my approach.

\section{PAYING FOR LESS RISKY PERFORMANCE}

Though the idea of pay for performance is decades old, until recently its only application had been to incentivize managers to improve shareholder returns. Since the recent financial crisis, however, it has become clear that the structure of banker pay has consequences for bank risk regulation. Bank examination and supervision, as well as capital requirements, impose important limits on bank risk taking and help assure bank solvency. However, these approaches are incomplete because they do not directly address managerial incentives. ${ }^{108}$ Instead of relying solely on these external influences, regulators may be able to bond bankers to more prudent banking practices with pay-performance incentives that include risk-sensitive instruments. At the same time, regulatory attention to the structure of management incentives may offer an important tool to enable more efficient tradeoffs between risk taking and regulation.

I propose to constrain bank risk taking by paying bankers in part with their banks' public subordinated debt securities. Empirical research shows that as the proportion of a CEO's wealth held in the form of firm debt increases relative to the value of her equity holdings, risk taking declines. Including debt in bankers' pay arrangements and making debt a greater share of their personal portfolios would reduce bankers' risk-taking incentives. The presence of this debt shifts bankers' personal interests away from riskpreferring equity, aligning their interests more closely with relatively riskaverse debtholders. ${ }^{109}$ This alignment also furthers regulators' interest in assuring banks' safety and soundness. ${ }^{110}$ Publicly traded subordinated debt securities are ideal for this task because the trading price will operate as a

\footnotetext{
108 See John, Saunders \& Senbet, supra note 21, at 97.

109 "Top management should ... be given incentives to act on behalf of debtholders to an adequate degree.... [P]roviding managers with compensation structures that have low pay-performance sensitivity may be optimal." John \& Qian, supra note 49, at 110.

Such compensation would admittedly dissuade bank executives from the traditional pursuit of value for shareholders, which is sometimes viewed as corporate managers' exclusive goal. This should not give us much pause, however. Bank governance has traditionally been recognized as presenting special concerns that deserve special governance tools. See supra notes 27, 51 and accompanying text.

${ }^{110}$ Perfect alignment of course may not necessarily be desirable; regulators might be perfectly happy with low-risk, low-growth strategies that might be socially suboptimal. Too much debt in managers' compensation packages may make them suboptimally risk averse, reducing long-term value. Rangarajan K. Sundaram \& David L. Yermack, Pay Me Later: Inside Debt and Its Role in Managerial Compensation, 62 J. FIN. 1551, 1553 (2007); David I. Walker, The Challenge of Improving the Long-Term Focus of Executive Pay, 51 B.C. L. REV. 435, 446-47 (2010).
} 
continuing referendum on risk taking at the bank. Market pricing of this debt will be particularly sensitive to downside risk, so its presence in bankers' personal portfolios will give bankers direct personal incentives to avoid excessive risk.

I first discuss recent learning on the effects of inside debt holdings on managerial risk taking. I next explain the use of sub debt for market discipline, describing its appropriate features. These sections provide the background for Part IV, which describes Bhagat and Romano's and Bebchuk and Spamann's recent banker pay proposals and compares these approaches with mine.

\section{A. Inside Debt Compensation}

Conventional wisdom holds that corporate managers' pay comes in two basic forms - cash and equity-based compensation ${ }^{111}$ — and that managers do not hold inside debt - the debt of their own firms. ${ }^{12}$ Recent research shows, however, that managers in fact do hold significant amounts of inside debt in the form of pensions and deferred compensation. ${ }^{113}$ These fixed aspects of executive compensation serve to some extent as debt-like compensation, since fixed compensation by definition promises a return that does not vary with firm performance. Instead, these forms of compensation give managers fixed claims against the firm.

These inside debt holdings can be substantial. By the time Jack Welch retired as the CEO of General Electric in 2001, the present value of his pension benefits plus deferred compensation was estimated to have exceeded $\$ 109$ million. ${ }^{114}$ Also at the end of 2006, at least seven public company CEOs held inside debt balances in excess of $\$ 100$ million. ${ }^{115}$ In one sample of Fortune $500 \mathrm{CEOs,}$, the pension component of total compensation for CEOs aged sixty-one to sixty-five was $40 \%$ larger on average than their base salary and equaled $23 \%$ of equity compensation. ${ }^{116}$

Though the possibility of including debt in executives' compensation arrangements has been largely ignored until quite recently, ${ }^{117}$ a nascent body of literature offers strong preliminary support for the proposition that holding fixed claims against the firm may dampen CEOs' risk-taking incen-

\footnotetext{
111 Sundaram \& Yermack, supra note 110, at 1551.

112 Alex Edmans \& Qi Liu, Inside Debt, 15 ReV. FIN. 75, 75-76 (2011).

113 Sundaram \& Yermack, supra note 110, at 1552; Chenyang Wei \& David Yermack, Investor Reactions to CEOs' Inside Debt Incentives, 24 REV. FIN. STUD. 3813 (2011).

114 Sundaram \& Yermack, supra note 110, at 1552.

115 Wei \& Yermack, supra note 113, at 48.

116 Sundaram \& Yermack, supra note 110, at 1554.

117 Id. at 1551 ("Implicit in virtually all of this [executive compensation] research is the assumption that managerial compensation consists of only two components, namely, cash and equity-linked instruments.").
} 
tives. ${ }^{118}$ Alex Edmans and Qi Liu show theoretically that inside debt may be part of an optimal compensation arrangement. ${ }^{119}$ While equity compensation incentivizes managers to exert more effort-thereby addressing the agency costs of equity-inside debt counters the risk-shifting incentives that accompany equity compensation, thereby reducing the agency costs of debt. ${ }^{120}$ Giving managers a stake in the value of the firm's debt makes them less willing to sacrifice its value to benefit shareholders. This is especially important when the firm is in distress. Debt compensation can improve managerial effort and firm value in distress situations because, unlike equity, debt is sensitive to the firm's liquidation value. That is, debtholders may still recover value when the firm is in distress. By contrast, equity is worthless once the firm is insolvent. ${ }^{121}$ Managers holding inside debt may therefore be less inclined to make risky bets when the firm gets into trouble. ${ }^{122}$ Especially for firms with high leverage - like banks — a high probability of default, and other severe risk-shifting incentives, debt may be an important component of optimal executive compensation. ${ }^{123}$

Empirical evidence also supports the idea that inside debt may dampen managers' risk-taking incentives. Several studies focus on CEO pensions and deferred compensation, recognizing these as forms of inside debt. Rangarajan Sundaram and David Yermack find that as the value of a CEO's pension increases relative to the value of her equity holdings, risk taking declines. ${ }^{124}$ The effect is especially strong when the CEO's debt-equity ra-

118 See Edmans \& Liu, supra note 112; Sundaram \& Yermack, supra note 110, at 1580-83; Joseph Gerakos, CEO Pensions: Disclosure, Managerial Power, and Optimal Contracting 23 (Pension Research Council, Working Paper No. 2007-5, 2007), available at http://ssrn.com/abstract=982180 (finding a positive association between the presence of pension benefits and higher quality debt ratings, suggesting that pension benefits may reduce risk taking).

119 Edmans \& Liu, supra note 112, at 78.

120 While Jensen and Meckling consider the agency costs of equity and debt separately, see Jensen \& Meckling, supra note 1, at 312, Edmans and Liu consider them simultaneously, thereby enabling analysis of the tradeoffs between incentivizing managerial effort and influencing investment choice, see Edmans \& Liu, supra note 112 , at 79 \& n.5.

121 Equity holders are indifferent to the firm's liquidation value because that value goes to pay creditors. So while equity-based compensation gives managers an incentive to avoid insolvency, it may also induce them to "inefficiently sacrifice liquidation value to gamble for solvency" when a firm is in distress. Edmans \& Liu, supra note 112, at 77. Debtholders will be less sanguine about squandering value on desperate investment strategies because their returns are fixed; they will not share in any (low probability but) stupendous returns beyond the fixed amount of their claims. Id.

122 The appropriate amount of debt depends on the relative magnitudes of the two different types of agency problems - shirking versus risk shifting. Id.

123 The appropriate amount of debt increases with leverage, the probability of default, and the manager's ability to affect liquidation values, while debt is reduced with increasing growth opportunities. See id. at 77-78.

124 Sundaram \& Yermack, supra note 110, at 1555. Sundaram and Yermack use "distance-todefault" as their measure of firm risk - basically the number of standard deviation decreases in firm value that would be required to put the firm in default. Id. They regress fixed effects panel data models 
tio exceeds her firm's debt-equity ratio. ${ }^{125}$ Chenyang Wei and David Yermack find evidence that investors expect firm managers to manage more conservatively as their inside debt holdings increase. ${ }^{26}$ Wei and Yermack examine the reaction of public debt and equity markets to new disclosures on the value of CEOs' pensions and deferred compensation in 2007. ${ }^{127}$ They find that when the CEO's inside debt-equity ratio exceeds her firm's, the disclosure triggers a wealth transfer from equity holders to debtholders. ${ }^{128}$ Bond prices rise, while equity prices fall. ${ }^{129}$ In addition, the price volatility drops for both debt and equity. ${ }^{130}$ These market reactions are consistent with the idea that investors expect managers to run their firms more conservatively - taking less risk - when they hold large inside debt positions.

Most recently, Xue Wang and I tested the effects of inside debt specifically in the context of the recent financial crisis. We show that inside debtequity ratios for $\mathrm{BHC}$ CEOs at the end of 2006 were positively associated with better $\mathrm{BHC}$ performance during the crisis and negatively associated with BHC risk taking. ${ }^{131}$

This recent literature on the effects of CEO debt holdings nicely frames the potential benefits of including publicly traded subordinated debt in bankers' pay packages and personal portfolios. Inside debt seems a natural corrective for the unique moral hazard and risk-taking inducements for bankers that derive from high leverage, equity incentives, and deposit insurance. With subordinated, publicly traded debt, market actors will continually assess banks' default risk and price the debt accordingly. Bankers will then see the real-time results of this continuing referendum on their risk taking in the value of their personal portfolios.

\section{B. Market Discipline through Public Subordinated Debt}

Subordinated debt securities improve on executive pensions and deferred compensation as an incentive device because subordinated debt, or

with separate intercepts for each unique CEO-firm pair. Id. at 1581; see also Gerakos, supra note 118, at 23 (finding a positive association between pensions and debt ratings).

125 When a CEO's debt-equity ratio exceeds her firm's debt-equity ratio, distance-to-default declines by 0.3 to 0.4 standard deviations, which is statistically significant. Sundaram \& Yermack, supra note 110 , at 1555 .

126 Wei \& Yermack, supra note 113, at 3814.

127 Beginning in 2007, the Securities and Exchange Commission began requiring more extensive executive compensation disclosures, including explicit valuations of officers' pension benefits and deferred compensation. 17 C.F.R. $\S 229.402$ (c)(2)(viii) (2007). Prior to the regulation's implementation, precise valuation of these items was quite complicated and required the gathering of significant information outside of the firm's public filings. Wei \& Yermack, supra note 113, at 3819.

128 Wei \& Yermack, supra note 113, at 3813-14.

${ }^{129}$ Id.

130 Id. at 3815.

131 Tung \& Wang, supra note 14, at 22-29. 
sub debt, imposes market discipline. ${ }^{132}$ Sub-debt holders are typically sophisticated institutional investors with the resources and expertise to monitor their borrowers, ${ }^{133}$ and issuing subordinated debt may impose market discipline on banks in at least two ways. First, debtholders will contract with the issuing bank for covenants that constrain the bank's risk taking. ${ }^{134}$ Second, the trading price of the subordinated debt is sensitive to the bank's risk taking. Sub debt is junior to depositor liabilities, and unlike insured depositors, sub-debt holders do not enjoy federal insurance against losses or repayment priority when a bank fails. If the bank were to fail, sub-debt holders would be repaid only after the repayment of all depositorsincluding uninsured depositors - and general creditors. ${ }^{135}$ Therefore, in the face of real trouble, debtholders may either act to enforce their covenantstypically a very public maneuver - or they may sell. In either case, information is made public.

The market for subordinated bank debt is well established, ${ }^{136}$ and banks engaging in excessively risky strategies will see their sub-debt trading prices drop. ${ }^{137}$ Market pricing therefore serves as a transparent and continuing signal of the riskiness of the bank's activities. Risk-related price fluctuations will directly affect bankers' wealth when the debt is included in their

132 The idea of requiring banks to issue public debt securities in order to impose market discipline on bank risk taking has been the subject of study for several decades. A 1986 study commissioned by the American Bankers Association recommended a mandatory requirement that banks issue subordinated debt. George J. Benston et al., Perspectives on SAFE And Sound Banking: Past, Present, AND FUTURE 192 (1986). Under the Gramm-Leach-Bliley Act, a large FDIC member bank wishing to control a financial subsidiary must have an issue of highly rated debt outstanding. Gramm-LeachBliley Act, Pub. L. No. 106-102, § 121, 113 Stat. 1338, 1373 (1999). The GLB Act also commissioned the Federal Reserve Board and the Treasury Department to study the feasibility of requiring large banks and bank holding companies to issue subordinated debt as a device to improve market discipline. Id. $\S 108,113$ Stat. at 1361-62; see also Paul Kupiec, Using a Mandatory Subordinated Debt Issuance Requirement to Set Regulatory Capital Requirements for Bank Credit Risks, in CAPITAL ADEQUACY Beyond BASEl: BAnKInG, SECurities, AND Insurance 146 (Hal S. Scott ed., 2005) (proposing a mandatory subordinated debt requirement).

133 Robert P. Bartlett III, Going Private but Staying Public: Reexamining the Effect of SarbanesOxley on Firms' Going-Private Decisions, 76 U. CHI. L. REV. 7, 15 (2009); Mark E. Van Der Weide \& Satish M. Kini, Subordinated Debt: A Capital Markets Approach to Bank Regulation, 41 B.C. L. REV. 195, 222 (2000).

134 Van Der Weide \& Kini, supra note 133, at 221-22.

13512 U.S.C. $\S 1821(\mathrm{~d})(11)(\mathrm{A})$ (2006).

136 See Laurence H. Meyer, Supervising Large Complex Banking Organizations: Adapting to Change, in PRUDENTIAL SUPERVISION, supra note 37, at 97, 103; infra note 147 and accompanying text.

137 Douglas D. Evanoff \& Larry D. Wall, Sub-Debt Yield Spreads as Bank Risk Measures, 20 J. FIN. SERVICES RES. 121, 133-35 (2001) (showing that sub-debt yield spreads perform slightly better than capital measures as predictors of banks' financial condition); Mark J. Flannery \& Sorin M. Sorescu, Evidence of Bank Market Discipline in Subordinated Debenture Yields: 1983-1991, 51 J. FIN. 1347, 1373-74 (1996) (demonstrating that bond yields reflect investors' pricing of bank risk taking); Diana Hancock \& Myron L. Kwast, Using Subordinated Debt to Monitor Bank Holding Companies: Is It Feasible?, 20 J. FIN. SERVICES RES. 147, 147 (2001) (finding that bonds of highest liquidity offer the most consistent pricing information for purposes of reflecting bank default risk). 
personal portfolios. In this way, the fine reflection of managerial risk taking generates both important incentive and information effects. It will incentivize bank officers to monitor risk carefully; it will also offer a clear signal to regulators and market participants to give special scrutiny to particular banks. ${ }^{138}$

Current banking law recognizes that bank subordinated debt may help harness private market risk assessment to complement regulators' efforts. For example, the largest FDIC member banks are required to issue longterm investment grade unsecured debt if they control a financial subsidiary. ${ }^{139}$ Market discipline, in the form of both market pricing and creditor enforcement actions, helps to curb regulatory forbearance problems. Current regulatory oversight depends heavily on administrative judgments and not on market assessments. Regulatory capital rules are based on accounting rules and administrative assessments of risk. Similarly, bank portfolio supervision turns largely on the administrative discretion of particular bank supervisors. Regulators may be reluctant to act against an insolvent bank, either because of political pressure from supporters of the shaky bank ${ }^{140}$ or because public action may expose regulators' past mistakes or lax oversight. Under these conditions, regulators might prefer to wait and see, hoping that the shaky bank will work its own way out of trouble. ${ }^{141}$ Strong public indicators of potential default risk, however, may prod regulators into action, as their failure to acknowledge a problem becomes more difficult to justify to the public. ${ }^{142}$

Subordinated debt also improves on equity as a form of bank capital and as a device for market discipline. As bank capital, sub debt cushions the bank from losses without the perverse incentives that come with equi-

138 Some evidence suggests that subordinated debt does influence managers' decisionmaking. See Kose John et al., Outside Monitoring and CEO Compensation in the Banking Industry, 16 J. CORP. FIN. 383, 384 (2010) (finding a statistically significant relation between the degree of sub-debt holder monitoring and pay-performance sensitivity); $c f$. Robert R. Bliss \& Mark J. Flannery, Market Discipline in the Governance of U.S. Bank Holding Companies: Monitoring Versus Influencing, in PRUDENTIAL SUPERVISION, supra note 37, at 107, 141 (finding evidence of monitoring but finding inconclusive results regarding influence).

139 Gramm-Leach-Bliley Act, Pub. L. No. 106-102, § 121, 113 Stat. 1338, 1373 (1999); see also William W. Lang \& Douglas D. Robertson, Analysis of Proposals for a Minimum Subordinated Debt Requirement, 54 J. ECON. \& BUS. 115, 116 (2002) (discussing differing subordinated debt requirements for the fifty largest banks controlling a financial subsidiary versus banks ranked fifty-one to one hundred in size).

140 See George J. Benston \& George G. Kaufman, FDICIA After Five Years, 11 J. ECON. PERSP. 139, 140-42 (1997) (describing the lax supervision of savings and loan associations in the 1980s as partially driven by political pressure).

141 Id. at 141-42 (describing regulatory forbearance problems among U.S. bank regulators).

142 See Charles W. Calomiris \& Andrew Powell, Can Emerging Market Bank Regulators Establish Credible Discipline? The Case of Argentina, 1992-99, in PRUDENTIAL SUPERVISION, supra note 37, at $147,157$. 
ty. ${ }^{143}$ Distress-related risk taking, which may include potentially highyielding negative-expected-value bets, may be bad for the stability of the bank but still good for equity holders. This sort of high-risk gamble is less a problem with subordinated debt than it is with equity. Because sub debt enjoys only limited upside, sub-debt holders will not see the same benefit from risky strategies that equity holders do. ${ }^{144}$ So sub-debt holders will be less willing than equity holders to sacrifice firm value on high-risk strategies to return the firm to solvency. For these same reasons, market pricing of subordinated debt is more sensitive to downside risk than equity is, which makes subordinated debt a superior device for market discipline. ${ }^{145}$ Including sub debt in bankers' pay and portfolios reinforces these advantages of subordinated debt relative to equity. ${ }^{146}$

\section{Features}

This section discusses important features of the publicly traded subordinated debt that would be used for banker compensation. The features of this debt are intended to enhance market discipline on banks, which would in turn incentivize bankers to avoid excessive risk once their compensation arrangements and personal wealth include such debt securities. The largest banks already issue subordinated debt, ${ }^{147}$ so feasibility is not an issue. ${ }^{148}$ These banks will be the most important for purposes of cabining systemic risk, and they are the ones most likely to significantly affect the deposit insurance fund.

\footnotetext{
143 See Paul Hamalainen, Mandatory Subordinated Debt and the Corporate Governance of Banks, 12 CORP. GOVERNANCE 93, 96 (2004).

144 See supra note 32 and accompanying text. In addition, sub debt has value even when the firm is insolvent, while equity has nothing left to lose. See supra note 121 and accompanying text.

145 See supra note 121 and accompanying text.

${ }^{146}$ An overarching caveat deserves mention. The implicit (or explicit) promise of a government bailout would frustrate attempts at imposing market discipline on banks and their managers. To the extent that debtholders believe that the government will not allow a given financial institution to fail, its debtholders will price their debt securities accordingly and will have weaker monitoring incentives. See Flannery \& Sorescu, supra note 137, at 1373-74 (finding that bond markets price bank default risk more carefully as the likelihood of a government rescue decreases). One possible way of addressing this species of moral hazard is to explicitly exclude debtholders by statute as beneficiaries of any future government rescue effort. Douglas D. Evanoff \& Larry D. Wall, Subordinated Debt as Bank Capital: A Proposal for Regulatory Reform, 24 ECON. PERSP. 40, 47 (2000).

147 At the end of 1998, forty-five of the fifty largest commercial banks and forty-eight of the fifty largest bank holding companies had issued subordinated debt. Lang \& Robertson, supra note 139, at 124; see also id. at 124, tbls. 3 \& 4 (breaking down by size the number of banks and bank holding companies that had subordinated debt issues outstanding at the end of 1998).

148 The fine tailoring of the terms of the subordinated debt for purposes of market discipline may be tricky, however, since the terms of sub-debt issuance are currently driven primarily by bank capital guidelines, which are not focused primarily on the market-disciplining role of subordinated debt. Evanoff \& Wall, supra note 146, at 43-44.
} 
Bank subordinated debt should have a maturity of at least eight to ten years. ${ }^{149}$ The debt should be issued relatively frequently in staggered tranches ${ }^{150}$ with bankers receiving debt from each issue. Bankers should be required to hold the debt for at least half of its maturity. This structure should offer continuing incentives for bankers to constrain risk taking at their banks.

The medium to long term of the debt gives public debtholders the appropriate incentive to police bank risk to assure long-range stability and to price the debt accordingly. ${ }^{151}$ Bankers holding the debt would have a similar perspective.

Periodic issuance of new debt would force the bank continually to return to the public capital markets for refinancing, subjecting the bank to frequent active monitoring by underwriters, investors, and rating agen-

149 Commentators interested in the market-disciplining effects of bank subordinated debt typically recommend at least a five-year maturity. SILAS KEEHN, BANKING ON THE BALANCE: POWERS AND THE SAFETY NET 36 (1988); Evanoff \& Wall, supra note 146, at 45; Lang \& Robertson, supra note 139, at 131.

150 KEEHN, supra note 149; Evanoff \& Wall, supra note 148, at 45 (recommending two issues per year). The proceeds of each issuance would be used to retire some portion of outstanding subordinated debt. For example, a bank might issue $\$ 100$ million worth of eight-year bonds every six months. By the end of year eight, the bank would have \$1.6 billion of subordinated debt outstanding, with $\$ 100$ million maturing every six months. The proceeds of each new issuance would be used to repay the maturing tranche of debt.

In terms of the total amount of sub debt outstanding, several studies recommend at least $2 \%$ of assets as a suitable minimum. Shadow Financial Regulatory Committee, Reforming Bank CAPITAL REGULATION 21 (2000) (recommending 2\% of assets); Evanoff \& Wall, supra note 146, at 45 (recommending at least 3\% of risk-weighted assets for the largest twenty-five banks); Hamalainen, supra note 143, at 101 (recommending 2\% of risk-weighted assets). Without accounting for risk weighting, it appears that large banks have somewhere in the neighborhood of $2 \%$ outstanding in the absence of any mandate. For example, as of September 30, 2009, JPMorgan Chase Bank had assets of about \$1.7 trillion and outstanding subordinated notes and debentures of about $\$ 28.5$ billion, which amounts to just under $1.7 \%$ of assets. JPMORGAN CHASE BANK, N.A., CONSOLIDATED REPORTS OF CONDITION AND INCOME FOR A BANK WITH DOMESTIC AND FOREIGN OFFICES-FFIEC 031, at 10-11 (Sept. 30, 2009) [hereinafter JPMORGAN REPORT], available at https://cdr.ffiec.gov/public/ManageFacsimiles.aspx (Report Type: Call $\backslash$ TFR; Single Date: 9/30/2009; Institution: JPMorgan Chase Bank, National Association). Similarly, as of September 30, 2009, Bank of America, N.A. had assets of $\$ 1.46$ trillion and subordinated notes and debentures outstanding of $\$ 25$ billion, which represents $1.7 \%$ of assets. BANK OF AMERICA, N.A., CONSOLIDATED REPORTS OF CONDITION AND INCOME FOR A BANK WITH DOMESTIC AND FOREIGN OFFICES-FFIEC 031, at 10-11 (Sept. 30, 2009) [hereinafter BANK OF AMERICA REPORT], available at https://cdr.ffiec.gov/public/ManageFacsimiles.aspx (Report Type: Call $\backslash$ TFR; Single Date: 9/30/2009; Institution: Bank of America, National Association). In addition, this amount gives some assurance of continuing secondary market liquidity, which is important for high quality price signals. Hancock \& Kwast, supra note 137, at 152 (noting that issue size, age of issue, whether the issuer is classified as a large complex banking organization, and overall bond market liquidity all improve the liquidity of bank subordinated debt).

151 The bank's ability to retire debt through buybacks or call options should be limited under the terms of the bond indenture. 
cies. ${ }^{152}$ So in addition to the medium- to long-term focus driven by the maturity of the bonds, bank managers have incentives toward continual shortterm vigilance in order to keep their borrowing costs low. A bank that takes on excessive risk will pay higher interest costs when it goes to sell subordinated debt in the public bond markets. ${ }^{153}$ At the limit, a shaky bank may be unable to issue new debt at any price, ${ }^{154}$ which sends a fairly clear market signal that the bank is in trouble. In effect, frequent issuance of subordinated debt marshals the capital markets to help keep bankers on a short leash. ${ }^{155}$

Regular injections of these debt securities into a banker's portfolio, along with holding requirements, assures that a banker will always own a significant amount of inside debt with a medium term to maturity that the banker cannot sell in the near future. ${ }^{156}$ These inside debt holdings would complement the twin goals of the bank's rolling debt issuance. Holding the bank's medium-term debt would encourage bankers to adopt a medium- to long-term perspective in their decisionmaking. The periodic receipt of bonds from new debt issues and the regular opportunity to sell would encourage managers' continuing vigilance regarding risk taking at the bank. In general, managers would be concerned about maintaining and increasing the values of their personal portfolios. Including this medium-term public debt would discourage excessive risk taking by giving managers some incentive to maintain the bank's medium-term solvency. ${ }^{157}$

\section{Bank-Level Debt to Counter Corporate Structure Effects}

The modern BHC structure, in which banks are held as wholly owned subsidiaries of diversified financial institutions, creates additional sources of risk to banks. It also informs the structuring of our public subordinated

152 See René Stulz, Does Financial Structure Matter for Economic Growth? A Corporate Finance Perspective, in Asli Demirgüç-Kunt \& Ross Levine, Financial Structure And EConomic Growth: A Cross-Country COMParison of Banks, Markets, and Development 143, 170-73 (2001).

${ }^{153}$ A bank executive might try to engineer a higher interest rate on the next periodic debt issuance by increasing bank risk. However, the size of the banker's existing debt holdings would deter such a strategy because the market would bid down the value of those existing holdings in the face of the increased risk. Structured properly, the executive would lose more on the value of her existing holdings than she would gain in terms of the higher interest rate on the new issue. I am indebted to Chuck Whitehead for pointing out this potential for gaming.

${ }^{154} \mathrm{Cf}$. Calomiris \& Powell, supra note 142, at 169 (describing the workings of the subordinated debt requirement in Argentina and the inability of weaker banks to accomplish new issuance).

155 Cf. Mitchell Berlin, Debt Maturity: What Do Economists Say? What Do CFOs Say?, Bus. Rev., Q1, 2006, at 3, 4 (explaining lenders' use of short-maturity debt to keep risky firms on a short leash).

${ }^{156}$ For example, a banker receiving annual allotments of eight-year bonds that she cannot sell for four years has a continuing incentive to maintain her bank's medium-term solvency.

157 Over time, the composition of a banker's portfolio may create suboptimal incentives because of earlier sales from the portfolio. Annual incentive pay should be structured to account for existing portfolio incentives and to adjust accordingly. See infra Part IV.C. 
debt requirement: the debt should be issued at the level of the banking subsidiary (the "bank"), and not the BHC. Public bank debt offers a much crisper market price signal regarding risk taking at the bank than would $\mathrm{BHC}$ debt or other BHC securities. Bank debt pricing therefore better tracks regulators' interest in bank safety and soundness and offers better incentives for bankers holding the debt. ${ }^{158}$

The BHC structure also complicates the task of identifying the bankers to be targeted with pay regulation. Management structures within BHCs vary. The CEO and other top officers of a banking subsidiary should clearly be covered by my proposed pay constraints. Holding company officers may need to be covered as well. Holding company officers typically have significant influence over policy decisions at banking subsidiaries and may even be officers of the banking subsidiaries. ${ }^{159}$ For example, Ken Lewis, the CEO, Chairman, and President of Bank of America Corporation, the nation's largest BHC, serves in these same capacities for Bank of America, N.A. ${ }^{160}$ its principal banking subsidiary and the nation's second-largest bank. ${ }^{161}$ When BHC officers wield important influence over a banking subsidiary's policy decisions, they should be made to hold subordinated debt of that bank. ${ }^{162}$

This section considers the effects of BHC structure on banker pay, the attendant incentives to take risk at the bank, and the use of bank-level subordinated debt as an antidote.

158 This is not to suggest that paying bankers with BHC debt or other securities would not be potentially useful in curbing BHC risk taking. But BHC risk is a different problem from the bank moral hazard and risk taking that comes with deposit insurance, which is the subject of both my proposal and competing proposals.

159 See Van Der Weide \& Kini, supra note 133, at 256 n.202 (noting that bank managers are also often managers of the BHC).

160 Bank of America Corp., supra note 16, at 16.

161 See Bank of America Corporation Financial Reports, IBANKNET, http://www.ibanknet.com/ scripts/callreports/getbank.aspx?ibnid=usa_1073757 (last visited Sept. 30, 2011) (showing Bank of America, N.A. as the largest banking subsidiary of Bank of America Corporation); Financial Reports of Leading Banks, IBANKNET, http:/www.ibanknet.com/scripts/callreports/fiList.aspx?type=031 (last visited Sept. 30, 2011) (showing Bank of America, N.A. as the second-largest bank by assets, with over $\$ 1.4$ trillion in assets).

${ }^{162}$ Even if the bank and BHC share no common officers, the bank officers serve at the pleasure of BHC management, since the BHC controls its banking subsidiaries through its equity ownership. So the influence of BHC management is likely to be felt keenly at the bank subsidiary level in any event. 
1. Noisy Proxies and Market Discipline.-The market discipline that publicly traded BHC debt or other securities might impose on banks and bankers would be weak compared to that imposed by debt issued at the bank subsidiary level. The trading price of BHC securities would only offer a noisy proxy for risk taking at its banking subsidiary because the BHC owns financial institutions in addition to the bank. Take Bank of America, depicted in Figure 2, as an example. As with most of the largest commercial banks, Bank of America, N.A. is the dominant financial institution within its holding company group, Bank of America Corporation (BAC). The bank represents $65 \%$ of BAC's total assets. ${ }^{163}$

FIGURE 2

BANK OF AMERICA HOLDING COMPANY STRUCTURE

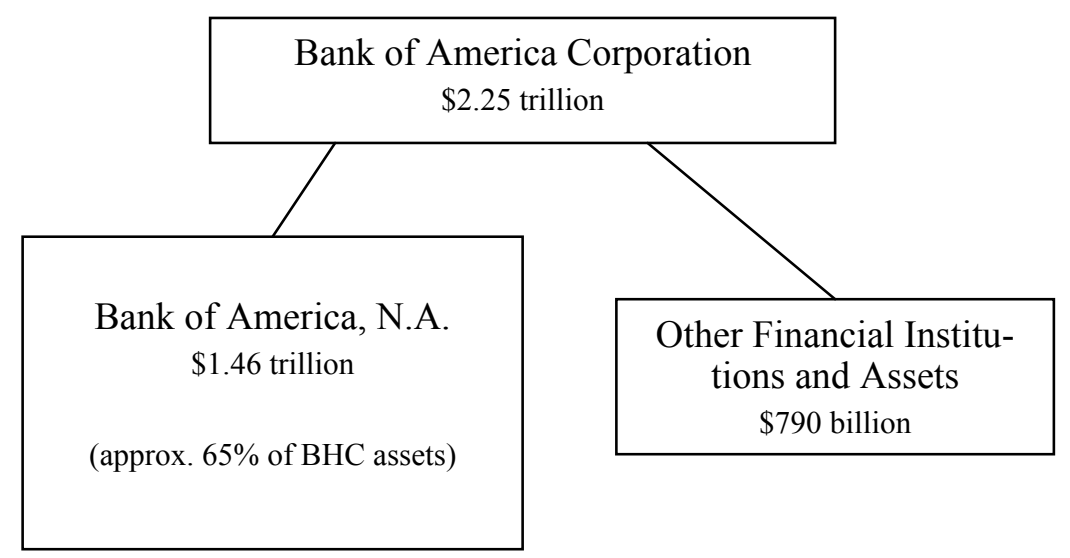

Because BAC holds $\$ 790$ billion in assets outside of its main bank, ${ }^{164}$ the trading prices of BAC securities reflect only a composite of information about the bank and the many additional entities comprising the other 35\% of BAC's assets. By contrast, the trading price of debt issued by the banking subsidiary would offer a more direct signal regarding risk taking at the bank. Bankers holding the bank's public debt would therefore have much greater incentive to focus on the bank's risk taking than if they held BAC securities. ${ }^{165}$

163 See Bank of Am. CORP., CONSOlidated Financial Statements for Bank Holding COMPANIES-FR Y-9C, at 11 (Sept. 30, 2009), available at http://www.ffiec.gov/nicpubweb/ NICDataCache/FRY9C/FRY9C_1073757_20090930.PDF (showing total BHC assets of \$2.25 trillion); BANK OF AMERICA REPORT, supra note 150, at 10-11 (showing bank assets of \$1.46 trillion).

164 This amount is simply the difference between BAC's total assets and its assets represented by Bank of America, N.A. See supra note 163.

165 The noisiness of the signal offered by BHC debt with respect to risk taking at the bank depends of course on the proportion of $\mathrm{BHC}$ assets represented by the bank. With a higher proportion, the noise 
2. BHC Equity Incentives.-Related to this parent-subsidiary issue, banking subsidiary debt compensation would respond directly to potentially excessive risk-taking incentives created by the typical practice of incentivizing bankers with BHC equity-based pay.

BHC executives set the direction for the entire organization, including the BHC's banking subsidiaries. Performance incentives for these executives typically take the form of BHC common stock and options, ${ }^{166}$ and not the equity of the banks themselves, which is not typically publicly traded. ${ }^{167}$ From the perspective of regulating risk taking at the bank, paying executives with $\mathrm{BHC}$ stock is problematic because it encourages bankers to take risks at the bank in order to benefit the BHC. This problem manifests in at least two important ways: layered leverage and affiliate conflicts.

a. Layered leverage.-The BHC structure creates at least two layers of leverage that affect banks. Unlike bank equity, which is junior in payout only to the bank's creditors, holding company equity is junior in payout to both the holding company's debt and the bank's debt. ${ }^{168}$ Assume for simplicity's sake that the BHC's only asset is its equity ownership in its subsidiary bank. Even if the bank has a positive net worth-that is, the value of its assets exceeds its liabilities and thus its equity has valueshareholders of this simplified BHC benefit only when the value of the bank's assets exceeds the amount of the bank's liabilities plus the amount of the holding company's liabilities. Otherwise, the value of the bank equity would go to satisfy BHC creditors. Therefore, positive but low returns from low-risk bets by the bank may be good for the bank but not for holding company equity holders. For them, only high-risk, high-return bets may be attractive. For bankers incentivized with BHC equity securities, the risktaking propensities are magnified by the outstanding debt at both levels. ${ }^{169}$

Related to this layered leverage, risk taking by a BHC or its other subsidiaries can affect the risk preferences at the bank. Risky bets by the bank's affiliates (or the bank itself) that reduce the value of holding company equity effectively increase holding company leverage, which as earlier noted increases risk-taking incentives at the holding company. This may

problem abates. Similar issues arise with the use of other BHC securities for banker pay, as would occur with the approaches of Bhagat and Romano, and Bebchuk and Spamann. See infra Part V.

${ }^{166}$ As earlier noted, these incentives are supplied not just through annual compensation but also through existing equity holdings, which typically dwarf the value of annual compensation. See supra note 93 and accompanying text.

167 Banks wholly owned by BHCs by definition do not issue publicly traded common stock, so BHC stock is the only common equity security available.

168 See Bebchuk \& Spamann, supra note 6, at 258-61.

169 Besides taking risky bets, bankers may also forego the positive but low returns from less risky bets. This is the problem of leverage-induced underinvestment. See Stewart C. Myers, Determinants of Corporate Borrowing, 5 J. FIN. ECON. 147, 154-55 (1977) (demonstrating that the presence of debt financing may cause managers to forego valuable but low-return projects because the returns would inure primarily or exclusively to creditors' benefit). 
cause greater risk taking at the banking subsidiary as well, since the combined leverage faced by bank managers incentivized with BHC equity is now greater. ${ }^{170}$

This effect may be especially pernicious in a systemic crisis. As bankers' BHC stock and option holdings lose value, leverage is effectively increased, exacerbating moral hazard throughout the banking industry. Bankers and other BHC shareholders have little to lose at that point and much to gain from high-risk, potentially high-return projects. ${ }^{171}$

b. Affiliate conflicts.-Independent of layered leverage effects, bankers with large BHC equity stakes may be willing to risk bank value in order to benefit the holding company-and themselves as BHC equity holders. For example, holding company management might force the major banking subsidiary within the BHC (say, BankCo, N.A.) to extend a risky loan to an unaffiliated firm (say, Shaky Debtor, Inc.) that owes significant sums to an affiliate within the BHC (say, BankCo Commercial Credit) in order to improve the prospects that Shaky Debtor, Inc. will be able to repay its loan to BankCo Commercial Credit. BankCo, N.A. might not have extended the risky loan without the intercession of BHC management or might have charged a much higher interest rate to account for the risk involved with the loan. Nevertheless, this loan might make sense from the BHC's perspective. Overall holding company value could be enhanced at the bank's expense, increasing the risk of bank failure. ${ }^{172}$

The magnitude of this potential conflict between the bank and BHC interests will depend on the proportion of $\mathrm{BHC}$ value that a given bank represents. As mentioned earlier, each of the largest banks is typically the dominant financial institution within its BHC, representing the lion's share of the BHC's revenues, profits, and assets. For example, JPMorgan Chase Bank, the nation's largest commercial bank, ${ }^{173}$ represents over $80 \%$ of the total assets of its BHC. ${ }^{174}$ Any misalignment of the interests of the BHC and its dominant banking subsidiary is therefore likely to be relatively small. The conflict may be greater at Bank of America, N.A., which as

\footnotetext{
${ }^{170}$ See Bebchuk \& Spamann, supra note 6, at 258-61. The situation is even worse with BHC equity options, which offer a large upside but, unlike equity, may have very little downside. See Walker, supra note 110 , at $446-47$.

171 See Bebchuk \& Spamann, supra note 6, at 271-72.

172 Banking regulations curb the most egregious of these problems, such as sweetheart loans for affiliates. However, investment decisions are notoriously difficult to police for these types of conflicts.

173 See Financial Reports of Leading Banks, supra note 161 (showing JPMorgan Chase Bank, N.A., as the largest U.S. bank by assets as of December 31, 2010, with $\$ 1.63$ trillion in assets).

174 See JPMorgan Chase \& Co., Consolidated Financial Statements for Bank Holding COMPANIES-FR Y-9C, at 11 (Sept. 30, 2009), available at http://www.ffiec.gov/nicpubweb/ NICDataCache/FRY9C/FRY9C_1039502_20090930.PDF (showing total BHC assets of \$2.04 trillion); JPMORGAN REPORT, supra note 150, at 10 (showing bank assets of $\$ 1.7$ trillion).
} 
previously noted represents only $65 \%$ of the total assets within Bank of America Corporation.

More generally, as the economic significance of a bank within its BHC decreases, the BHC's interests are more likely to diverge from those of the bank, making BHC equity compensation for bank managers increasingly problematic from the standpoint of bank safety and soundness. Goldman Sachs and Morgan Stanley offer extreme examples. Long-time investment banks, these firms converted to bank holding companies in the midst of the recent financial crisis, a move that gave them permanent access to the Federal Reserve's lending facilities. ${ }^{175}$ Unlike traditional commercial banking organizations, the commercial banking operations of these two newly minted BHCs account for only a small portion of their business activities. For example, Morgan Stanley, depicted in Figure 3, is the nation's sixth largest BHC. Its one commercial bank-though among the thirty largest commercial banks - represents less than $8.5 \%$ of the holding company's total assets. ${ }^{176}$ Managers incentivized with holding company equity may be inclined to put the bank at risk in order to benefit the holding company and other affiliates. ${ }^{177}$

\footnotetext{
175 Andrew Ross Sorkin \& Vikas Bajaj, Radical Shift for Goldman and Morgan, N.Y. TIMES, Sept. 22, 2008, at A1, available at http://www.nytimes.com/2008/09/22/business/22bank.html.

176 Morgan Stanley, CONSOlidated Financial Statements For BANK Holding COMPANIES-FR Y-9C, at 11 (Sept. 30, 2009), available at http://www.ffiec.gov/nicpubweb/ NICDataCache/FRY9C/FRY9C_2162966_20090930.PDF (showing total BHC assets of \$770 billion); Morgan Stanley Bank, N.A., CONSOlidated Reports of CONDITION AND INCOME FOR A BANK WITH DOMESTIC OFFICES ONLY-FFIEC 041, at 10 (Sept. 30, 2009), available at https://cdr.ffiec.gov/ public/ManageFacsimiles.aspx (Report Type: Call $\backslash$ TFR; Single Date: 9/30/2009; Institution: Morgan Stanley Bank, National Association) (showing bank assets of $\$ 65$ billion). As for Goldman Sachs Group, the nation's fifth largest BHC, banking assets make up only $13 \%$ of its total assets. GoLDMAN

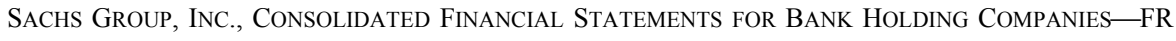
Y-9C, at 11 (Sept. 30, 2009), available at http://www.ffiec.gov/nicpubweb/NICDataCache/FRY9C/ FRY9C_2380443_20090930.PDF (showing total BHC assets of $\$ 882$ billion); GOLDMAN SACHS BANK USA, CONSOlidated REPORTS OF CONDITION AND INCOME FOR A BANK WiTH DOMESTIC OFFICES ONLY-FFIEC 041, at 9 (Sept. 30, 2009), available at https://cdr.ffiec.gov/public/ ManageFacsimiles.aspx (Report Type: Call $T F R$; Single Date: 9/30/2009; Institution: Goldman Sachs Bank) (showing bank assets of $\$ 115$ billion). Finally, MetLife, traditionally a life insurance company, is the seventh largest U.S. BHC. Its banking assets make up only $2.4 \%$ of BHC assets. METLIFE, INC., Consolidated FinanCial Statements For BANK Holding Companies-FR Y-9C, at 11 (Sept. 30, 2009), available at http://www.ffiec.gov/nicpubweb/NICDataCache/FRY9C/FRY9C_2945824 20090930.PDF (showing total BHC assets of $\$ 535$ billion); METLIFE BANK, N.A., CONSOLIDATED REPORTS OF CONDITION AND INCOME FOR A BANK WITH DOMESTIC OFFICES ONLY-FFIEC 041, at 9 (Sept. 30, 2009), available at https://cdr.ffiec.gov/public/ManageFacsimiles.aspx (Report Type: Call \TFR; Single Date: 9/30/2009; Institution: MetLife Bank) (showing bank assets of $\$ 13$ billion).

177 This inclination may explain why large banking subsidiaries do not issue publicly traded stock. The presence of minority shareholders would impede BHC efforts to exploit synergies across subsidiaries because putting the bank at risk to benefit its affiliates within the BHC group might attract charges of self-dealing and lawsuits by the minority. See Evanoff \& Wall, supra note 137, at 125 (suggesting this as a hypothesis).
} 
N O R T H W E S T E R N UN IVER S T Y L A W R E VIE W

FIGURE 3

MORGAN STANLEY HOLDING COMPANY STRUCTURE

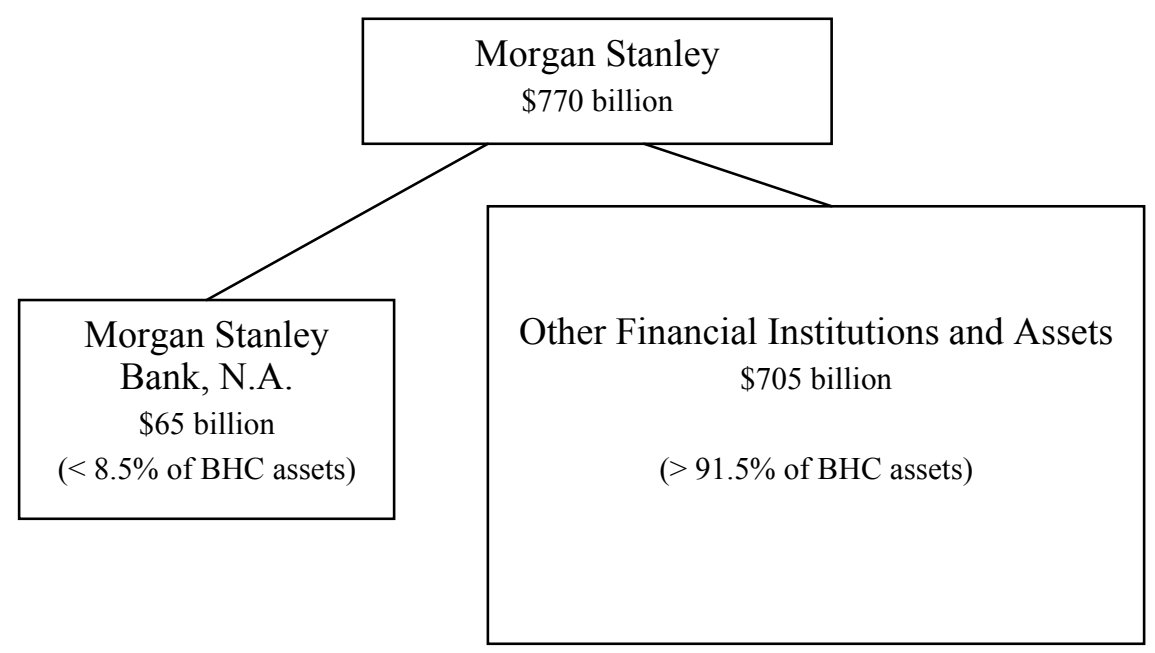

Granted, regulatory supervision extends to BHCs and their nonbank activities, ${ }^{178}$ and affiliate transactions attract special scrutiny. ${ }^{179}$ However, regulatory oversight may be inconsistent or unreliable, and it may be difficult to police the myriad business strategies that banks might undertake to benefit their nonbank affiliates. Especially given that BHCs' nonbank activities are riskier than banking, and therefore potentially more profitable, BHC equity incentives may encourage bank risk taking to boost these potentially more profitable activities.

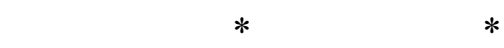

Banker pay in the form of subordinated debt issued at the bank level would directly counter the BHC-equity-fueled incentive to bet the bank.

\footnotetext{
178 For example, BHCs are subject to risk-based supervision and must comply with capital adequacy rules. See FED. RESERVE SYS., Framework FOR Risk-FocuSEd SuPERVISION OF LARGE COMPLEX INSTITUTIONS 1, 4 (1997), available at http://www.federalreserve.gov/boarddocs/SRletters/1997/ sr9724a1.pdf (describing the application of the Federal Reserve's risk-focused supervisory framework to bank holding companies); BD. OF GOVERnors of THE FED. RESERVE SYS., APPLYING SUPERVISORY Guidance and Regulations on the Payment of Dividends, Stock Redemptions, and Stock REPURCHASES AT BANK HOLDING COMPANIES, SR 09-4, at 2 (Mar. 27, 2009), available at http://www.federalreserve.gov/boarddocs/srletters/2009/SR0904.pdf (discussing BHC capital adequacy requirements).

${ }^{179}$ Federal Reserve Act, 12 U.S.C. § 371c(a)(4) (2006) (requiring that all covered transactions between a bank and its affiliates be consistent with safe and sound banking practices); $§ 371 \mathrm{c}$ (b) (requiring that certain transactions with an affiliate be on market terms); Regulation W, 12 C.F.R. § 223.21-.56 (2010) (implementing § 371c(a)-(b)).
} 
Whether to overcome layered leverage or to enhance the value of affiliates within the BHC, either BHC strategy comes at the bank's expense, and bank sub debt may be a well-matched antidote.

\section{COMPARING OTHER APPROACHES}

In addition to my own proposal, two important academic proposals have recently emerged to restructure bank executive compensation in the service of financial regulation, one from Sanjai Bhagat and Roberta Romano, and the other from Lucian Bebchuk and Holger Spamann. This Part discusses these efforts and compares them with my own.

In addition to issues specific to each approach, both proposals suffer from two important shortcomings when compared to my sub-debt approach. First, both proposals rely on holding company securities as incentive pay. As earlier discussed, because market pricing of BHC securities may offer only a very noisy proxy for risk taking and performance at a given banking subsidiary, such securities may provide bankers only weak incentives with regard to activities at the bank. ${ }^{180}$ Second, both proposals focus exclusively on the structure of annual compensation, ignoring the much more significant incentive effects of bankers' existing portfolios of equity and other claims on their banking firms. ${ }^{181}$ Tailored adjustment of bankers' existing portfolio incentives would be difficult to achieve under either of these approaches. These two issues are better addressed with subordinated debt issued directly by important banking subsidiaries. ${ }^{182}$

I first consider each proposal on its own merits. I then compare them with my bank sub debt approach.

\section{A. Bhagat and Romano: Long-Term Restricted Stock}

Remaining true to the traditional equity-based focus of incentive compensation, Sanjai Bhagat and Roberta Romano have devised a simple yet

\footnotetext{
180 See supra Part III.D. Recall that the target bankers for our incentive compensation include the members of the management group with policy authority over the bank. This will likely include the bank CEO and other top bank officers. It is likely also to include BHC officers, who typically have significant influence over banking subsidiaries' policy. Further, it is not uncommon that certain BHC officers also hold key officer positions at a banking subsidiary. See supra notes 159-62 and accompanying text.

181 Other scholars have recognized that focusing exclusively on annual compensation is not sufficient. See John E. Core et al., Executive Equity Compensation and Incentives: A Survey, FRBNY ECON. POL'Y REV., Apr. 2003, at 27, 30 (“A key point in analyzing executive incentives is that an executive's incentives from stock and options are properly measured by portfolio incentives .... [O]ne cannot determine whether an executive has an appropriate level of incentives by examining newly granted restricted stock and options compensation in a given year." (citations omitted)).

182 Moreover, banking subsidiaries' debt securities may be periodically rolled over-redeemed and reissued - in order to impose continuing capital market discipline on banks and bankers. See supra Part III.C. This would be quite difficult to accomplish under either the Bhagat-Romano or BebchukSpamann approach.
} 
radical restricted stock proposal. They argue that all equity-based compensation should take the form of restricted stock and restricted stock options. An executive would not be permitted to sell the stock or exercise the options until two to four years after the executive leaves the firm. ${ }^{183}$ According to Bhagat and Romano, the two- to four-year post-retirement holding period would give executives appropriate intermediate-term incentives. Two years is sufficiently lengthy a period to deter managers from the pursuit of short-term profits from taking undue risks or manipulating earnings or public statements during their tenure. The four-year upper limit on the holding period would be sufficient for the effects of the executive's decisions and strategies to be realized. Their proposal is targeted primarily at TARP recipient firms, but they note that their argument could be extended to all financial firms that enjoy federal deposit insurance. ${ }^{184}$

The lengthy holding period is the central feature of the Bhagat-Romano proposal. Restricted stock and option compensation is not new, but the typical vesting period under these compensation plans is three to five years after the grant date, ${ }^{185}$ and the executive is typically required to remain employed by the company at the time the stock or options vest. ${ }^{186}$ By contrast, Bhagat and Romano's proposal would require the executive to have left the firm and a number of years to have elapsed before the executive could cash out. Bhagat and Romano note some of the distortions that arise with this compensation structure. Managers under such stringent holding periods will be underdiversified, reducing the risk-adjusted expected return of their portfolios. ${ }^{187}$ Bhagat and Romano suggest simply increasing the size of the stock or option grant, which would increase the expected return to compensate for the underdiversification. ${ }^{188}$ But that approach is inefficient insofar as each additional share of stock or option compensation costs the firm more than its value to the executive. ${ }^{189}$

\footnotetext{
183 Bhagat \& Romano, supra note 7, at 361.

184 Id. at 367.

185 Frederick W. COOK \& CO., The 2008 TOP 250: LONG-TERM InCENTIVE GRANT PRACTICES FOR EXECUTIVES 17 (2008) (noting that options vest in three years for about 50\% of large U.S. companies, in four years for about $30 \%$ of firms, and in five years for about $15 \%$ of firms).

${ }^{186}$ Walker, supra note 110 , at 448 n.64.

187 Bhagat \& Romano, supra note 7, at 367 . Hedging would be prohibited, as it would defeat the incentive effects of the restricted stock compensation. $I d$. at 368 .

${ }^{188} I d$.

189 Walker, supra note 110, at 458 (noting that executives would effectively be receiving more of something they value less). There is the added problem that because current rules on executive compensation disclosure require valuation of stock awards at the market price- and would therefore not account for executives' underdiversification discount- the value of these stock awards would be overstated, potentially exacerbating public outrage over executive compensation levels. See id.
} 
Their general concept has some appeal. Like subordinated debt, equity prices also incorporate a firm's solvency risk. ${ }^{190}$ With sufficiently long holding periods, equity holdings and equity-based incentives might curb managers' short-term risk taking. After all, managers whose equity-based payday comes after they have resigned their executive positions must consider the longer-term effects of their decisions and not just quarterly results.

On the other hand, the delayed gratification inherent in this lengthy holding period creates important problems. First, it weakens any incentive effects. ${ }^{191}$ Managers facing uncertain payoffs many years into the future may be too conservative in their project selection or may simply care less about firm performance, especially given the significant "control gap"- the period after retirement and before their equity payoffs, during which they will have no influence over the firm's performance. ${ }^{192}$ In addition, the potentially long delay between performance and pay creates a liquidity problem for executives because a large portion of their compensation cannot be spent for years after it is earned. ${ }^{193}$ Acknowledging this problem, Bhagat and Romano suggest that the limit on tax deductibility of non-performancebased compensation be raised from $\$ 1$ million to $\$ 2$ million $^{194}$ in order to allow for greater cash compensation to executives being paid with restricted stock. This alleviates the liquidity problem to some extent. However, higher levels of fixed compensation also blunt the performance incentives that drive their proposal.

In addition, using retirement from the firm as a trigger gives good CEOs an incentive to retire too soon. Bhagat and Romano argue that the holding period is not really so onerous, given that the median CEO tenure for large U.S. companies is five years. ${ }^{195}$ The median, however, may not fully capture the magnitude of the premature retirement problem. For policymaking purposes, the variance of CEO tenure also matters. A wide dispersion may mean that a large proportion of CEO's must wait fifteen or twenty years to cash out their earliest granted restricted stock or options.

\footnotetext{
190 This useful effect is qualified by the "noisy proxy" problem that arises from the use of BHC securities to compensate bankers as opposed to securities issued by the bank itself. See supra Part III.D.

191 George Ainslie \& John Monterosso, Will as Intertemporal Bargaining: Implications for Rationality, 151 U. PA. L. REv. 825, 830 (2003) (explaining experimental evidence showing that the value of the reward is "inversely proportional to delay").

192 This control gap may increase their incentives to actively participate in the wise choice of their successors, but it is not clear whether their current incentives are inadequate.

193 See Bhagat \& Romano, supra note 7, at 368.

194 See I.R.C. $\S 162(\mathrm{~m})(1)(2006)$ ("[N]o deduction shall be allowed under this chapter for applicable employee remuneration... to the extent that the amount of such remuneration... exceeds $\$ 1,000,000 . ”) ;$ Bhagat \& Romano, supra note 7, at 368.

${ }^{195}$ They point out that executives facing a seven- to nine-year wait to cash out their earliest received stock and option grants would not be unique to financial firms, as general partners of private equity firms must often wait seven to ten years to receive the bulk of the carried interest portion of their compensation. Bhagat \& Romano, supra note 7, at 369.
} 
Perversely, since the best performing CEOs are likely to enjoy the longest tenure, they are likely to feel most keenly the constraints of the BhagatRomano holding period. The best CEOs may retire earlier than is optimal for their firms in order to be able to cash out sooner.

\section{B. Bebchuk and Spamann: Paying by the Slice}

Lucian Bebchuk and Holger Spamann propose that, for financial firms, banker pay should be linked not just to improved shareholder returns, but to firms' enterprise value as represented by a diversified basket of each firm's securities. ${ }^{196}$ Banker pay should be tied to the value of a proportionate slice of all the BHC's securities ${ }^{197}$ - its preferred stock and bonds, as well as common equity - thereby linking pay to "a larger part of the corporate pie." 198 Including common and preferred shares and bonds in this basket would expose managers to a broader range of downside risks to which the firms' various investors are subject and would tend to deter excessive risk taking. ${ }^{199}$

Bebchuk and Spamann's approach takes important steps in the right direction. Including BHC preferred stock and bonds as part of executives' incentive pay would offer a clear improvement to the current commonshareholder-focused, equity-based approach. Because holders of preferred stock and bonds generally prefer less risk than common shareholders, inclusion of these securities more closely aligns managers' incentives with those of regulators interested in safety and soundness and the preservation of the FDIC insurance fund. ${ }^{200}$

196 Bebchuk \& Spamann, supra note 6, at 253.

197 Id. at 284 (proposing that executive pay be tied to "a set percentage of the aggregate value of common shares, preferred shares, and all outstanding bonds"). Though the authors do not explicitly distinguish BHC securities from those of banking subsidiaries, their approach only works with holding company securities, since banking subsidiaries do not issue public equity - their common stock is held entirely by their BHC-or preferred stock.

198 Id. at 283. For example, for TARP firms, because of the government's large stake in the preferred stock of these firms, executive pay should track aggregate returns on a specified percentage of the value of all common and preferred shares. This would align managers' incentives somewhat with shareholders' interests but also somewhat with the public interest in having TARP investments repaid. See id. at 283-84.

199 Bebchuk and Spamann suggest additional benchmarks to which executive pay might be linked in order to curb risk taking. Perhaps executive pay could be reduced based on the amount of any government payments made to support the bank - including deposit insurance payments — during the one-year period after the executive's departure from the firm. See id. at 284. The authors suggest that any expected increase in future government payments could be proxied by multiplying the value of the bank's (presumably insured) deposits by any increase in the implied probability of default that may be inferred from the price of credit default swaps. $I d$.

${ }^{200}$ Bebchuk and Spamann also argue that bankers' pay should be regulated, or at least carefully monitored, as an important facet of banking regulation generally, independent of the current crisis and the attendant government support. See id. at 278-79. 
On the other hand, while this approach will generally reduce managers' risk-taking proclivities at the $\mathrm{BHC}$ level and has some intuitive investordemocratic appeal, it does not precisely respond to the original problem. The problem is not underrepresentation of $\mathrm{BHC}$ investors but moral hazard at the banking subsidiary and risk externalization to the public fisc. Because bank managers' individual situations will vary in ways that are not correlated with their BHCs' capital structures, there is no conceptual basis for assuming that executive pay in the form of a representative slice of the BHC's securities will offer appropriate incentives to internalize risk at the banking subsidiary. Managers' existing holdings of their firm's securities will vary, for example. ${ }^{201}$ Because of the strong incentive effects of these existing holdings and their variation across managers, ${ }^{202}$ paying by the slice may not be appropriate for each individual manager. Adherence to strict proportionality across classes of the bank's securities in structuring incentive compensation forsakes flexibility that may be useful in tailoring compensation to address specific managers' existing incentives.

\section{Comparing}

For purposes of constraining bank risk taking, long-term restricted $\mathrm{BHC}$ stock or pay-by-the-BHC-slice compensation may offer some improvement over the standard BHC equity approach that currently dominates banker pay structures. However, my bank sub-debt approach is superior for its focus on bank risk, its stronger market discipline, and its utility in tailoring bankers' portfolio incentives.

Bank-issued subordinated debt offers a clearer market signal concerning risk taking at the bank than long-term BHC equity or a slice of BHC securities, ${ }^{203}$ giving market actors, regulators, and bankers better information about default risk and more finely tailoring managerial incentives to risk regulatory goals. This market discipline may be enhanced through a program of regular periodic issuance of new debt securities, which requires the bank to continually access public capital markets for fresh capital and sub-

\footnotetext{
201 Banks' and BHCs' growth opportunities also vary, which affects the optimal level of risk taking, though growth opportunities may correlate with capital structure. Managers' inside debt holdings in the form of pensions and deferred compensation also vary, and these have been shown to affect managers' risk-taking proclivities. See supra Part III.A.

202 See supra Part III.

203 Adding more basket components to account for future government payments required to support the bank, as Bebchuk and Spamann suggest, further complicates any market pricing signal, especially if the component depends on actual future payments, for which no readily available market pricing exists. Even relying on credit default swap (CDS) pricing may be problematic, as CDS markets are fragmented and opaque. Subordinated debt markets, by contrast, are likely to be more liquid and transparent for large banks.
} 
ject itself to primary market review. ${ }^{204}$ This periodic market review is unworkable for compensation arrangements that rely on long-term restricted BHC equity or that attempt to mirror BHC capital structures. ${ }^{205}$

No approach based solely on BHC securities can directly address layered leverage and affiliate conflict problems. ${ }^{206}$ Overall BHC risk taking might be reduced with long-term restricted BHC stock or by-the-slice BHC securities for bankers but that would not necessarily incentivize bankers to reduce risk at the bank.

Pay-by-the-BHC-slice does better than long-term restricted stock for addressing layered leverage, since the BHC debt securities would have value even if the BHC were insolvent. ${ }^{207}$ Pay-by-the slice might therefore reduce bankers' incentives to gamble in high leverage or distress situations as compared with standard BHC equity compensation. Again, however, because bankers holding BHC securities would be concerned primarily with BHC value, affiliate conflicts would remain problematic. Bankers might still bet the bank to save the BHC.

Subordinated bank debt offers superior incentives along these margins compared to long-term BHC equity or BHC securities by the slice. Subordinated debt compensation more directly reduces the layered leverage incentives from BHC equity because bankers would have a direct stake in the value of debt at the bank level. Affiliate conflicts would also be much more aggressively ameliorated because sacrificing the bank to benefit BHC equity would have a direct negative impact on bankers' personal bank sub-debt holdings.

${ }^{204}$ Weaker banks may even find themselves unable to float the required issue, an event with serious consequences for the bank and one that sends a clear market signal. Cf. Calomiris \& Powell, supra note 142, at 169 (describing inability of weaker Argentine banks to issue required subordinated debt).

205 There is no public market for Bhagat and Romano's long-term restricted BHC stock. And the trading price of the outstanding BHC common stock would not offer a useful metric for valuing longterm restricted stock because of the extreme holding period applicable to BHC executives, which puts their holdings in a completely different category. As for Bebchuk and Spamann's pay-by-the-slice proposal, BHCs might issue new publicly traded common and preferred shares and debt periodically. However, unlike regular bank sub-debt issues, periodic by-the-BHC-slice issuances would be difficult to structure as important capital-raising events for the BHC because large periodic issues of common shares would dilute existing shareholders' equity holdings. Nominal issuances, of course, would not impose stringent market review.

In any event, for both long-term restricted BHC stock and by-the-BHC-slice securities, the market would be reviewing the financial health of the BHC and not the soundness of the bank.

206 See supra Part III.D.2.

207 Long-term restricted BHC stock might temper bet-the-bank strategies for improving BHC value to some extent. Bankers' long time horizon might discourage them from extreme short-term risky strategies. However, bankers holding even long-term restricted BHC stock care primarily about BHC returns. Facing distress-induced high BHC leverage, for example, bankers might reason that the long run may never arrive if the BHC fails. So short-run gambles for BHC solvency may still be attractive, even if they require sacrificing the bank. 
Sub-debt compensation can also directly manage bankers' portfolio incentives. Annual adjustments to bankers' pay could account for changes in the composition of bankers' personal portfolios and changes in banks' risk profiles. By contrast, neither long-term restricted BHC stock compensation nor pay-by-the-BHC-slice can offer this sort of fine-tuning of portfolio incentives. $^{208}$ Again, any portfolio of BHC securities may offer only coarse incentives with respect to risk taking at the bank and may even increase bank risk taking in some circumstances.

\section{IMPLEMENTATION}

The regulation of bankers' pay should not be viewed as a substitute for existing banking regulation but rather as an integral part of the regulatory structure. ${ }^{209}$ With an additional tool to encourage banker prudence and to monitor bank safety and soundness, regulators may be able to more finely balance the competing concerns of risk regulation and bank profitability. For example, better prudential incentives in executive pay arrangements may justify lower deposit insurance premiums, less stringent capital requirements, or less burdensome reporting requirements or onsite examinations for a given bank.

This Part discusses two important implementation issues: how to go about setting substantive targets for bankers' inside debt portfolios and how to encourage banks to use bank sub-debt compensation in pursuit of banker portfolio management. Given the complexity of large banks and BHCs, the attendant complexity of banking regulation, and the novelty of using banker pay as an instrument of risk regulation, much will have to be learned through experience. This Part sketches some key considerations moving forward.

208 As earlier noted, Kenneth Feinberg, the special master overseeing compensation at the largest seven TARP recipient companies, slashed salaries in favor of long-term stock grants, which vest over four years. See supra notes 103-04 and accompanying text. While this approach may respond to popular outrage over executive pay, its superficial popular appeal does not offer a long-term solution to executive risk taking. Though annual compensation is easy to observe, for executives with even a few years' tenure, annual pay is almost certainly dwarfed by the value of the executives' preexisting portfolios of their banks' securities. Even if every annual stock grant carries a four-year vesting period, in a short time the value of an executive's unrestricted stock will exceed that of her restricted stock, so shortterm incentives may outweigh longer-term concerns.

Lengthening the holding period, of course, runs into greater liquidity, diversification, and delayed gratification problems discussed in the context of the Bhagat-Romano proposal.

209 As John, Saunders, and Senbet note, bank regulation that accounts for the incentives of top management will be more effective. John, Saunders \& Senbet, supra note 21, at 97. 


\section{A. Setting Debt-Equity Targets}

Calibrating the optimal debt-equity targets for bankers' pay and portfolios might be tricky and will depend on bank-specific factors, ${ }^{210}$ as well as the corporate structure effects discussed above. ${ }^{211}$ For example, the amount of bank-level subordinated debt in a banker's portfolio should be calibrated to counter the incentive effects of her BHC equity holdings and layered leverage on risk taking at the bank. Greater layered leverage will require greater bank sub-debt holdings as a counterweight to the risk-inducing incentives of leverage. ${ }^{212}$ A consideration of the size and economic importance of the bank relative to the BHC's other subsidiaries will also be important. If the bank is the dominant subsidiary in the $\mathrm{BHC}$, as is the case with JPMorgan Chase Bank, ${ }^{213}$ affiliate conflicts are less of a concern. ${ }^{214}$ By contrast, when the bank is less important economically to the $\mathrm{BHC}$ as a whole, such as Morgan Stanley Bank, ${ }^{215}$ more bank sub-debt holdings should be required of the relevant bankers. Greater bank sub-debt holdings will help bankers resist the temptation to take risky bets at the bank to benefit affiliates, since greater risk at the bank will result in a negative price reaction in the public debt market and a reduction in the value of bankers' bank sub-debt holdings.

In addition, the existing personal asset portfolios of individual bankers will affect the structure of the optimal compensation contract. As already noted, inside debt in the form of pensions and deferred compensation has important effects on managerial risk taking, ${ }^{216}$ and these debt holdings should also be taken into account. ${ }^{217}$ With these various considerations, bankers' personal debt-equity ratios can be adjusted to maintain appropriate risk-taking incentives in the face of new conditions affecting the bank or market price movements that might otherwise skew the weighting of bankers' portfolios.

\footnotetext{
210 The inside debt literature identifies a number of factors: leverage, capital structure, investment opportunities, ownership structure, and default risk. See Bagnani et al., supra note 60, at 454 (finding that the effects of equity-based pay on managers' risk taking is not monotonic); Edmans \& Liu, supra note 112 , at 78 (noting that the optimal amount of debt increases with leverage, the probability of default, and managers' ability to affect liquidation values, and decreases with growth opportunities); John, Saunders \& Senbet, supra note 21, at 96 (noting that bank managers' risk-shifting incentives depend crucially on the characteristics of the bank's investment opportunities).

211 See supra Part III.D.

212 See supra notes 168-71 and accompanying text.

213 See supra note 174 and accompanying text.

214 BHC equity incentives will still need to be addressed, of course.

215 See supra note 176 and accompanying text.

216 See supra Part III.A.

217 Bankers' pensions and deferred compensation are likely to be obligations of their holding companies and not of the banking subsidiaries. Therefore, the effects of this inside BHC debt on risk taking at the banks are likely to be indirect, dependent on the corporate structure of the BHC. See supra Part III.D.
} 


\section{B. Implementation Incentives}

Because of each bank's unique situation and the fine judgments required to optimize compensation arrangements, strict regulatory mandates seem inadvisable. Generalized mandates are likely to offer a poor fit for many banks, and mandates may be difficult to revise in the face of changed circumstances.

Instead, banking regulators could offer guidelines and regulatory incentives to encourage appropriate amounts of subordinated debt in bankers' pay arrangements, while at the same time preserving the discretion of boards of directors to set pay. For example, executive pay structures could be included as a factor in the setting of deposit insurance premiums. ${ }^{218}$ The current deposit insurance pricing scheme requires the FDIC to grade each bank on its capital ratios and other information and to assign it to one of four risk categories. Within each category, pricing is then determined based on additional bank-specific factors. ${ }^{219}$ The FDIC could similarly grade executive compensation, relying on a handful of grades to differentiate compensation schemes from a prudential regulatory perspective. ${ }^{220}$ Grading could reflect, among other things, the debt-equity composition of execu-

${ }^{218}$ John, Saunders \& Senbet, supra note 21, at 98 (proposing that risk-based pricing of deposit insurance should incorporate features of bank managers' compensation).

219 FED. DEPOSIT INS. CORP., CAPITAL GROUPS AND SUPERVISORY GROUPS, http://www.fdic.gov/ deposit/insurance/risk/rrps_ovr.html (last visited Oct. 1, 2011).

${ }^{220}$ Even before the recent financial crisis, bank executives' compensation was subject to regulatory scrutiny to assure that it was not excessive and would not lead to a material financial loss. See, e.g., First Nat'l Bank of Eden v. Dep't of Treasury, 568 F.2d 610, 611 (8th Cir. 1978) (per curiam) (affirming an order of the Comptroller of the Currency finding that excessive compensation constituted an unsafe or unsound banking practice).

Section 39(c) of the Federal Deposit Insurance Corporation Improvement Act of 1991 (FDICIA) required that bank regulators prescribe standards for executive compensation as part of safety and soundness regulation. 12 U.S.C. $\S 1831$ p-1(c)(1)(a) (2006). Interagency guidelines on the matter followed. Interagency Guidelines Establishing Standards for Safety and Soundness, 12 C.F.R. §364 app. A (2010). However, the guidelines on executive compensation added little to the statutory language. See Schooner, supra note 99 , at 892.

Especially relevant for our inquiry, regulators have scrutinized incentive compensation structures under this framework, rejecting arrangements that create perverse risk-taking incentives. See id. at $873-$ 75 \& n.63; see also COMPTROLLER OF THE CURRENCY ADM'R OF NAT'L BANKS, INSIDER ACTIVITIES: COMPTROLLER's HANDBOOK 13 (2006) (cautioning that banks should prevent the payment of compensation that could lead to material financial loss to the bank). Regulators have also imposed limits on executive compensation, including conditions or prohibitions on raises and bonus payments. See Schooner, supra note 99, at 878. Regulators have ordered banks to conduct prospective comprehensive reviews of their compensation systems, $i d$. at 882 , and have even required banks to submit incentive compensation plans for regulators' approval. See Order to Cease and Desist to Westsound Bank, No. FDIC-08-038b, at 4-5 (Mar. 10, 2008), available at http://www.fdic.gov/bank/individual/enforcement/ 2008-03-08.pdf. Regulators have taken an especially dim view of the enforceability of executive severance agreements once a bank has become insolvent or has entered receivership. See Schooner, supra note 99, at 904-11. Further elaboration of guidelines to encourage some form of subordinated debt compensation does not seem a great stretch, especially in light of the financial crisis and the role that executive compensation has played. 
tives' pay packages and personal portfolios and the specific features of the component securities, all in the context of each bank's situation. This grading could then be incorporated into insurance pricing. ${ }^{221}$ Such an approach would be consistent with the renewed regulatory attention to financial institutions' incentive pay arrangements mandated by the Dodd-Frank Act. ${ }^{222}$

Relying on regulators to incorporate banker pay arrangements into their discretionary regulatory strategies carries certain risks, of course. In addition to the standard regulatory agency conflicts, ${ }^{223}$ risk-based pricing of deposit insurance is not easy to implement as a technical matter, especially with respect to the largest banks, because of the difficulty of quantifying the credit risk in a bank's loan portfolio. ${ }^{224}$ Perhaps because of this difficulty, risk-based pricing has not historically differentiated very finely among banks: almost all banks have paid the same lowest rate. ${ }^{225}$ Such a premium structure offers only weak incentives for banks to reduce risk. In addition, even if insurance pricing better differentiated among banks, for some BHCs deposit insurance costs might be trivial relative to the BHC's overall activities. In that situation, even high premiums would be insufficient to induce socially desirable changes in banker pay arrangements. ${ }^{226}$ More drastic inducements might be required, such as adjustment of banks' capital requirements to account for executive pay and portfolio structures, which would directly affect bank risk taking and profitability.

Though regulatory intervention in this area may be tricky, my proposal nevertheless enhances the regulatory tool kit for encouraging prudent bank-

221 See John, Saunders \& Senbet, supra note 21, at 96-97.

222 Dodd-Frank Wall Street Reform and Consumer Protection Act, Pub. L. No. 111-203, § 956, 124 Stat. 1376 (2010); see supra note 106 and accompanying text.

223 See Frederic S. Mishkin, Evaluating FDICIA, in 9 RESEARCH IN FINANCIAL SERVICES: PRIVATE AND PUBliC POLICY 17 (George Kaufman ed., 1997) (discussing principal-agent problems in banking regulation). Regulators may forbear from taking action against a faltering bank, either because of political pressure from the bank's allies or because regulators would rather delay exposing their own regulatory failings in the hope that the bank might work its own way out of trouble. Id.

224 Id. at 25.

225 Benston \& Kaufman, supra note 140, at 149 (finding that in 1996, almost all banks qualified for the two lowest risk categories); Mishkin, supra note 223, at 25 (noting that as of 1997, well over 90\% of banks paid the lowest premium rate). The Federal Deposit Insurance Reform Act of 2005 gave the FDIC some greater discretion to implement risk-based premium classifications. George G. Pennacchi, Deposit Insurance 7 (Aug. 2009) (unpublished manuscript), available at http://www.cbpp.illinois.edu/ pdf/research/George_DepInsRevGP.pdf. At the time of its adoption, only $45 \%$ of banks were being charged the minimum rate. Id. As of June 30, 2008, only $45 \%$ of the Risk Category I (safest) large banks were paying the minimum rate. 74 Fed. Reg. 9525, 9527-28 (Mar. 4, 2009) (to be codified at 12 C.F.R. pt. 327).

${ }^{226}$ This weak deterrence from high deposit insurance premiums applies to risk taking at the bank more generally. As earlier noted, for a bank that represents only a small part of a BHC's business activities, BHC managers may be willing to take risks at the bank to benefit other BHC subsidiaries. See supra Part III.D.2. Increased deposit insurance costs might be a trivial consideration. I am indebted to David Walker for raising this point. 
ing. ${ }^{227}$ Even an imperfect approach to encouraging debt compensation offers an improvement over the current situation. ${ }^{228}$

\section{CONCLUSION}

I have proposed a new approach to compensating bankers that explicitly incorporates market discipline and a pay-for-performance strategy to constrain excessive risk taking. The key feature of my approach is to include banks' subordinated debt securities as part of bankers' compensation. In addition, I argue that the primary focus for structuring banker pay should be on the composition of their personal portfolios of their banks' securities and other claims on their banks. The current spotlight on annual pay alone misses the much stronger influence that managers' personal portfolios exert on their risk-taking incentives.

Using bank subordinated debt to adjust bankers' portfolios away from excessively risky strategies has important advantages over existing approaches, which ignore portfolio effects and rely solely on BHC securities, and which may provide only a noisy signal of risk taking at BHCs' banking subsidiaries.

Important details of this approach will need to be worked out through practical experience. In this time of critical regulatory reexamination and experimentation, bonding bankers to less risky strategies seems a worthy project.

${ }^{227}$ An overarching caveat concerning the possibility of a government bailout deserves mention. See supra note 146 .

228 Moreover, despite these difficulties, the FDIC has begun to consider tying premiums to bankers' compensation arrangements. Joe Adler, Plan to Link Premiums to Comp Already Under Fire, AM. BANKER, Jan. 8, 2010, at 1. This is surely a step in the right direction. As part of their efforts to reduce systemic risk, bank regulators should monitor executive compensation arrangements and incorporate this scrutiny as part of their supervisory function. 
N O R T H W ESTER N UN IVERS IT Y LA W RE VIE W 